
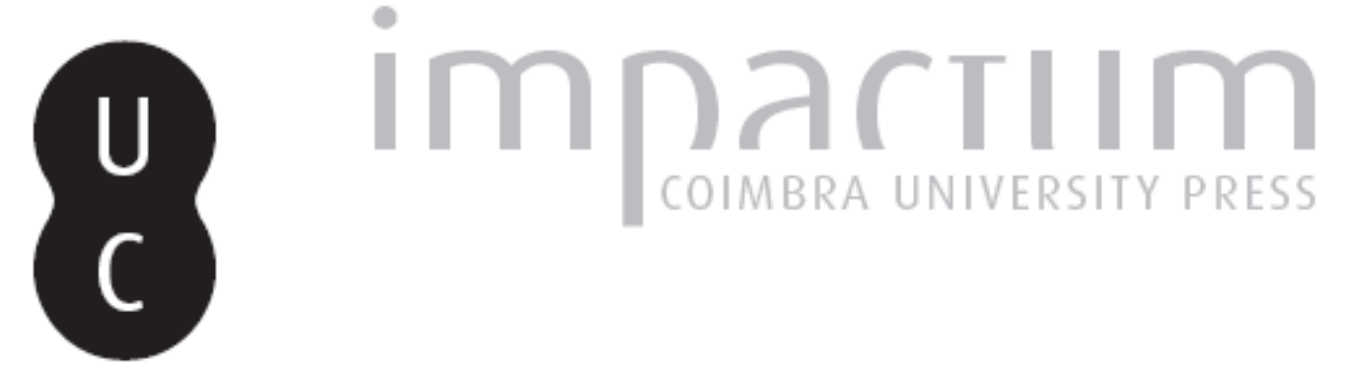

As entradas da Inquisição, na Vila de Melo, no século XVII: pânico,
integração/segregação, crenças e desagregação social

Autor(es): $\quad$ Paiva, José Pedro

Publicado por: Imprensa da Universidade de Coimbra

URL persistente:

URI:http://hdl.handle.net/10316.2/43697

DOI:

DOI:https://doi.org/10.14195/2183-8925_25_6

Accessed : $\quad$ 26-Apr-2023 10:14:39

A navegação consulta e descarregamento dos títulos inseridos nas Bibliotecas Digitais UC Digitalis, UC Pombalina e UC Impactum, pressupõem a aceitação plena e sem reservas dos Termos e Condições de Uso destas Bibliotecas Digitais, disponíveis em https://digitalis.uc.pt/pt-pt/termos.

Conforme exposto nos referidos Termos e Condições de Uso, o descarregamento de títulos de acesso restrito requer uma licença válida de autorização devendo o utilizador aceder ao(s) documento(s) a partir de um endereço de IP da instituição detentora da supramencionada licença.

Ao utilizador é apenas permitido o descarregamento para uso pessoal, pelo que o emprego do(s) título(s) descarregado(s) para outro fim, designadamente comercial, carece de autorização do respetivo autor ou editor da obra.

Na medida em que todas as obras da UC Digitalis se encontram protegidas pelo Código do Direito de Autor e Direitos Conexos e demais legislação aplicável, toda a cópia, parcial ou total, deste documento, nos casos em que é legalmente admitida, deverá conter ou fazer-se acompanhar por este aviso.

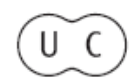



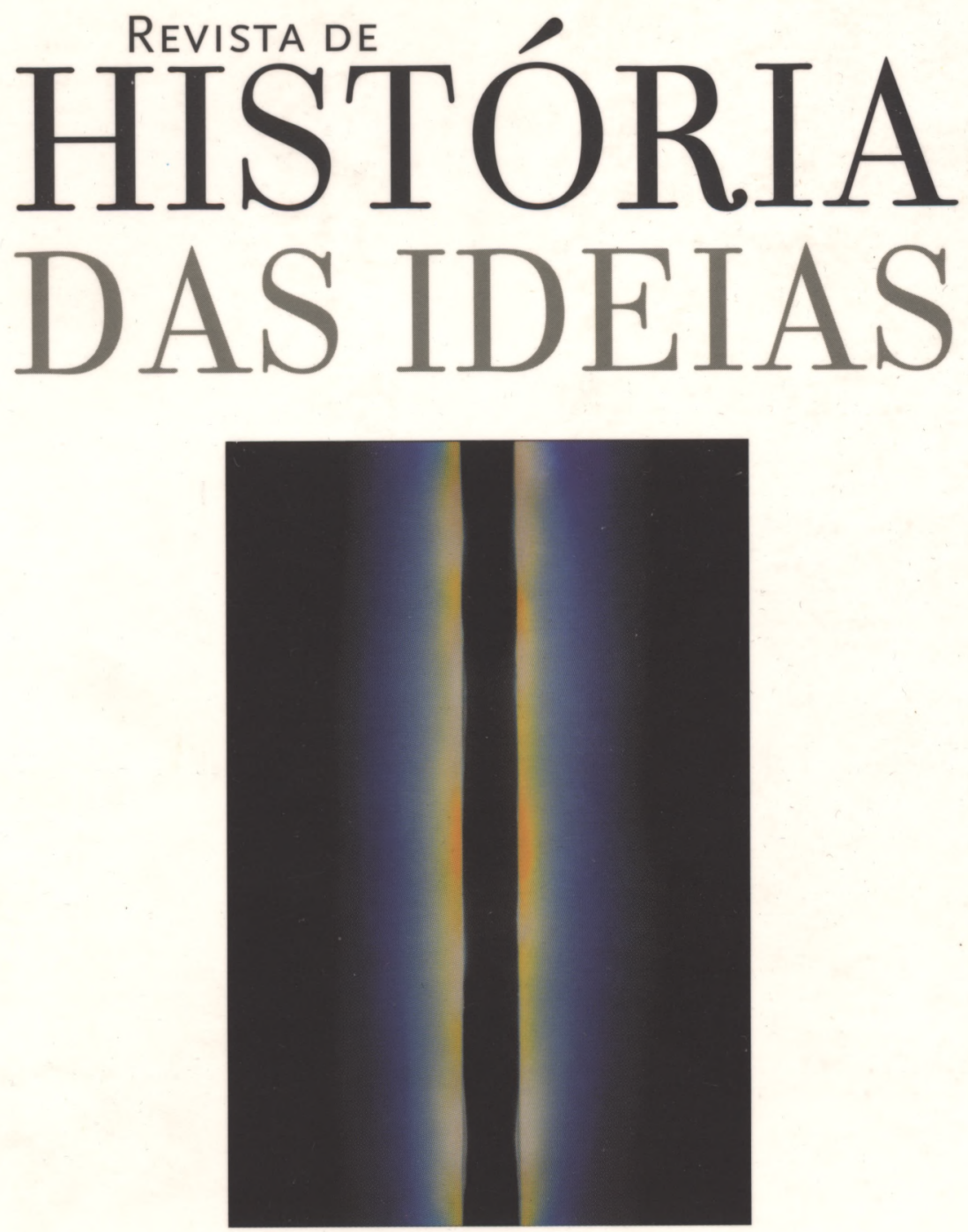

TOLERÂNCIAS, INTOLERÂNCIAS

\author{
Volume 25, 2004
}

INSTITUTO DE HISTÓRIA E TEORIA DAS IDEIAS

Faculdade de Letras da Universidade de CoImbra 


\section{AS ENTRADAS DA INQUISIÇÃO, NA VILA DE MELO, NO SÉCULO XVII: PÂNICO, INTEGRAÇÃO/SEGREGAÇÃO, CRENÇAS E DESAGREGAÇÃO SOCIAL}

\section{Introdução}

Os vestígios da presença judaica na região de Melo, na Serra da Estrela, remontam à primeira metade do século XIV. Um documento de 1334, que assinala uma dívida de Domingos Eanes, de Folgosinho, a um judeu de Gouveia chamado Isaque Guedelha, constitui o mais ancestral vestígio que actualmente se conhece dessa realidade ${ }^{(1)}$.

Dados posteriores registam a existência de uma judiaria em Melo, surgida na sequência da vinda de judeus expulsos de Castela, em 1492(2), bem como a criação de uma sinagoga na vila de Gouveia, em $1496^{(3)}$, o ano da publicação do édito Manuelino que decretava a expulsão dos

* Faculdade de Letras da Universidade de Coimbra/Centro de História da Sociedade e da Cultura.

(1) Ver Maria José Ferro Tavares, “O difícil diálogo entre judaísmo e cristianismo", in Carlos Moreira Azevedo (Dir.), História Religiosa de Portugal, Lisboa, Círculo de Leitores, 2000, vol. I, p. 57.

(2) Ver Maria José Pimenta Ferro Tavares, "Os Judeus em Portugal no século $\mathrm{XV}^{\prime \prime}$, in João Medina (Dir.), História de Portugal dos tempos pré-históricos aos nossos dias, Amadora, Clube Internacional do Livro, 1995, vol. VI, p. 11.

(3) Ver Manuel Augusto Rodrigues, "A inscrição hebraica de Gouveia", O Instituto. Revista Científica e Literária, vol. CXXX, 1968, p. 254. 
judeus e mouros de Portugal e a subsequente conversão forçada e violenta da comunidade ao cristianismo ${ }^{(4)}$.

Após este episódio da expulsão e conversão forçada dos judeus muitos permaneceram na região. Também por estas paragens se conhecem conflitos e motins contra os cristãos-novos de origem judaica que denotam as dificuldades de integração e os fenómenos de segregação de que foram alvo, mesmo ainda antes da instalação da Inquisição em Portugal. Alexandre Herculano foi o primeiro a dar conta de um acto de sacrilégio perpetrado contra uma imagem de Nossa Senhora, em Gouveia, que originou um alvoroço contra os cristãos-novos da vila acusados de o terem cometido. Na sequência de diligências efectuadas pelo poder régio e pelo bispo de Coimbra, D. Jorge de Almeida, três dos presumíveis culpados foram queimados em Lisboa, acusados de heresia, no ano de $1531^{(5)}$.

A presença da comunidade cristã-nova em Melo e noutras regiões vizinhas da Beira interior era volumosa, se bem que não se possam fornecer quantitativos demográficos precisos, e desde cedo preocupou os inquisidores, mesmo numa altura em que o Tribunal, estabelecido definitivamente em Portugal no ano de 1536, dava os seus passos iniciais e se organizava. Em 1564/65, um visitador da Inquisição passou por Gouveia, altura em que as primeiras denúncias contra judaizantes devem

(4) Sobre o assunto ver Alexandre Herculano, História da origem e estabelecimento da Inquisição em Portugal, Lisboa, Bertrand, 1975, tomo 1, pp. 113-159 (a edição original desta obra é de 1854-59), Fortunato de Almeida, História da Igreja em Portugal, nova edição, Porto/Lisboa, Liv. Civilização, 1967-71, vol. II, pp. 351-355, J. Lúcio de Azevedo, História dos cristãos-novos portugueses, Lisboa, Liv. Clássica Editora, 1975, pp. 57-62, Maria José Pimenta Ferro Tavares, Judaísmo e Inquisição. Estudos, Lisboa, Editorial Presença, 1987, pp. 17-66 e Francisco Bethencourt, "A expulsão dos Judeus", in Diogo Ramada Curto (Dir.), O Tempo de Vasco da Gama, Lisboa, Comissão Nacional para as Comemorações dos Descobrimentos Portugueses e Difel, 1998, pp. 271-280.

(5) Ver Alexandre Herculano, História da origem e estabelecimento da Inquisição em Portugal, Lisboa, Bertrand, 1975, vol. 1, pp. 198-206, onde estes episódios são reconstituídos a partir da Symmicta Lusitana e originais arquivados no Instituto dos Arquivos Nacionais/ Torre do Tombo (a partir de agora sempre referido pelas siglas IAN/TT), Corpo Cronológico (carta dos juízes ordinários de Gouveia, de 8 de Novembro de 1528 e de uma devassa efectuada pelo licenciado Sebastião Duarte, em Setembro de 1529). 
ter sido registadas ${ }^{(6)}$. Poucos anos antes, em 1558, a Inquisição de Lisboa processara o primeiro natural de Melo. Tratava-se de Guiomar do Campo, mulher viúva, ao tempo já residente na cidade de Lisboa, acusada por dois filhos de fazer jejuns judaicos. Posteriormente, em 1562, foi de novo processada e "relaxada ao braço secular", por relapsia no delito de judaizante ${ }^{(7)}$. A partir deste momento a região ficou sob a mira do Tribunal da Fé. No último quartel do século XVI, numa altura em que o tribunal distrital de Coimbra se instalava e não dispunha ainda de meios para uma actuação mais concertada, eficaz e geograficamente ampla, foram presos, em processos isolados, mais cinco habitantes ou naturais da vila dos senhores de Melo, quatro por judaizarem e um por blasfemo ${ }^{(8)}$.

No decurso do século XVII, a Inquisição de Coimbra fez três entradas na vila de Melo que causaram uma maciça razia da comunidade cristã-nova. A primeira iniciou-se com cinco prisões efectuadas em 18 de Maio de 1601 e concluiu-se com um auto-da-fé celebrado em Coimbra, aos 22 de Agosto de 1627, no qual saiu condenado o último natural de Melo que se pode ligar a este episódio ${ }^{(9)}$. No total, foram celebrados 57 processos, tendo seis, ou seja $10.5 \%$, terminado com a aplicação da sentença de relaxamento ao braço secular ${ }^{(10)}$. Violência inusitada, mesmo considerando tratar-se este um dos tempos fortes da ferocidade inquisitorial, como bem mostrou José Veiga Torres ${ }^{(11)}$.

(6) Ver Elvira Mea, A Inquisição de Coimbra no século XVI. A instituição, os homens e a sociedade, Porto, Fundação Eng. António de Almeida, 1997, p. 228.

(7) Cf. IAN/TT, Inquisição de Lisboa, processo $n^{\circ} 5248$.

(8) Tratava-se de Francisco Gonçalves, cristão-velho, cardador, que sustentava que Jesus Cristo, quando veio ao mundo, também devia "ser putanheiro", cf. IAN/TT, Inquisição de Coimbra, processo 7119 (auto de 1590). Os quatro processos de judaizantes encontram-se em IAN/TT, Inquisição de Coimbra, processos n. ${ }^{\circ} 9123$ (auto de 1570), 1391 (auto de 1571), 10038 (auto de 1571) e Inquisição de Lisboa, processo $\mathrm{n}^{\circ} 5797$ (auto de 1587).

(9) Ver lista de processados que se publica em anexo.

(10) Na prática apenas em 4 casos essa sentença foi de facto executada (IAN/ /TT, Inquisição de Coimbra, processos $\mathrm{n}^{\circ} 201$ (auto de 1608), $\mathrm{n}^{\circ} 8037$ (auto de 1608), $\mathrm{n}^{\circ} 3946$ (auto de 1608) e $\mathrm{n}^{\circ} 6845$ (auto de 1623), pois um dos condenados foi relaxado em estátua (IAN/TT, Inquisição de Coimbra, processos $n^{\circ} 4253$ (auto de 1602) e outro beneficiou do perdão geral de 1605 (IAN/TT, Inquisição de Coimbra, processo $\left.n^{\circ} 3117\right)$.

(11) Ver José Veiga Torres, "Uma longa guerra social. Novas perspectivas para o estudo da Inquisição portuguesa. A Inquisição de Coimbra", Revista de História 
Esta primeira entrada em Melo aconteceu em simultâneo com o ataque da Inquisição de Coimbra noutra frente, Guimarães, e após episódio que fez estremecer a instituição. Reporto-me ao célebre caso dos falsários de Bragança que originou a prisão de cristãos-velhos acusados de judaizarem ${ }^{(12)}$. Em suma, foi desencadeada num tempo de expansão e consolidação da máquina inquisitorial - Romero de Magalhães assim considera o período que decorre entre 1573-1604 - abalada ainda em 1605 pela concessão de um perdão geral que abriu as portas da liberdade a muitos naturais da vila de Melo e, finalmente, concluída numa fase de reorganização da instituição, sob a batuta do inquisidor geral D. Pedro de Castilho, após o choque causado pelo referido perdão ${ }^{(13)}$. Tempos difíceis para a Inquisição, que o caso de Melo demonstra que ela soube superar, não perdendo o rasto à perseguição de alguns daqueles que em 1605 tinham sido libertos ${ }^{(14)}$.

A segunda entrada foi desencadeada com a prisão de um Gaspar Rodrigues Frois, em 3 de Abril de 1652, e terminou com a condenação de Catarina de Cáceres, em $1674^{(15)}$. Nesta leva contabilizam-se 21 processos

das Ideias, vol. 8, 1986, pp. 63-65. Os valores apresentados para o tribunal de Coimbra encaixam genericamente nos que o autor anteriormente apresentara para o total nacional da acção inquisitorial, ver "Uma longa guerra social: os ritmos da repressão inquisitorial em Portugal", Revista de História Económica e Social, vol. 1, 1978, pp. 55-68. Compare-se a percentagem de relaxados em Melo com as compendiadas por Francisco Bethencourt para o total nacional (o valor máximo apresentado é de $7,4 \%$ de relaxados) e facilmente se perceberá a violência a que aqui se alude, ver Francisco Bethencourt, História das Inquisições Portugal, Espanha e Itália, Lisboa, Círculo de Leitores, 1994, p. 275.

(12) Ver Elvira Mea, A Inquisição de Coimbra no século XVI..., ob. cit., p. 372 e 474-80. Por esta altura, em Beja, houve episódio semelhante.

(13) Sobre os ritmos da acção inquisitorial nesta fase é indispensável a consulta de Joaquim Romero Magalhães, "Em busca dos tempos da Inquisição (1573-1615)", Revista de História das Ideias, vol. 9, 1987, pp. 191-228. Para o caso concreto dos ciclos aqui referidos ver p. 194 e 214.

(14) O perdão geral foi estabelecido pelo breve de Clemente VIII, Postulat a nobis, de 23 de Agosto de 1604, publicado nas três cidades da Inquisição em 16 de Janeiro de 1605, ver J. Lúcio de Azevedo, História dos cristãos-novos portugueses, Lisboa, Liv. Clássica Editora, 1975, p. 162. Vinte réus de Melo recebem essa notícia e são libertados entre 18 e 20 de Janeiro, ver por exemplo, IAN/TT, Inquisição de Coimbra, processo $\mathrm{n}^{\circ} 9657$.

(15) Ver lista de processados que se publica em anexo. 
e apenas um relaxado em "ossos e estátua"(16). Tratou-se de uma incursão mais branda nos números e nas penas aplicadas, o que a dizimação anterior pode ajudar a perceber, e que acabou por ser quebrada pela suspensão da acção do Tribunal, decretada em $1674^{(17)}$.

Uma terceira entrada, já de dimensão muito menor, ocorreu com a prisão de cinco réus, todos da mesma família, em 1690, que saíram em auto-da-fé no ano seguinte ${ }^{(18)}$.

Ao todo, cerca de oito dezenas de indivíduos foram fustigados pela acção inquisitorial, todos, com excepção de um único, por judaizarem ${ }^{(19)}$. Não disponho de dados demográficos consistentes para este período. Mas sabendo-se que, em 1721, Melo teria 663 "pessoas"(20), não será exagerado supor que, adicionando o total de indivíduos de facto processados e todos os familiares directos, se pode dizer que pelo menos um quarto da população local foi envolvida.

No concelho de Gouveia, a freguesia de Melo, a julgar pelos processos instaurados pela Inquisição, foi a localidade mais afectada pela repressão inquisitorial. Mas não foi a única. A comunidade cristã-nova dispersava-se por outras terras do concelho e as entradas de Melo provocaram muitas outras detenções. Conhecem-se processos de moradores em Arcozelo (4), Folgosinho (1), Gouveia (28), Nabainhos (9) e Nabais (5). Fora dos limites do concelho Linhares, Trancoso, Celorico da Beira, Covilhã e Guarda são exemplos de localidades onde os perseguidos de Melo tinham familiares, igualmente perseguidos pelo Tribunal. Ao longo do século XVII, a malha inquisitorial apertou-se sobre esta região central da Beira interior.

Opresente estudo debruça-se sobre estas entradas inquisitoriais em Melo e visa reconstruir a sua dinâmica e os impactos que provocou na vida comunitária local e nos indivíduos que foram objecto desta perseguição.

(16) Trata-se de Gaspar Rodrigues Frois que faleceu nos cárceres, em 5 de Fevereiro de 1667, IAN/TT, Inquisição de Coimbra, processo $n^{\circ} 4688$.

(17) Entre 1674 e 1681 a acção do Tribunal foi suspensa por decisão papal, ver J. Lúcio de Azevedo, História dos cristãos-novos portugueses, ob. cit., pp. 306-321.

(18) Ver lista de processados que se publica em anexo.

(19) Ver nota 8.

(20) Cf. Arquivo da Universidade de Coimbra, Informações paroquiais de 1721, $\mathrm{n}^{\circ} 158$ (Melo). 
Os cerca de 80 processos gerados por esta imensa actividade, que são a fonte documental mais utilizada nesta abordagem, consentem, entre outros aspectos, o estudo da dinâmica das incursões da Inquisição numa dada localidade, as suas consequências na vida local e permitem ainda desenhar certos traços de caracterização da comunidade cristã-nova, bem como conhecer os mecanismos/estratégias da sua integração social. São estas as abordagens que seguidamente se propõem, numa incursão que se desenvolve em três momentos: primeiro reconstituir-se-á toda a dinâmica concreta da actuação inquisitorial no contexto local, em segundo lugar propor-se-á uma caracterização da comunidade cristã-nova em Melo durante o período em que foi objecto desta repressão do Santo Ofício, em terceiro lugar perscrutar-se-ão os efeitos provocados pelo choque e pela violência da actuação do Tribunal da Fé na comunidade.

\section{A dinâmica das "entradas" da Inquisição}

Para principiar, procure perceber-se a dinâmica destes processos de entrada, admitindo desde já que os padrões aqui enunciados podiam ter uma configuração distinta nas cidades maiores e, sobretudo, nas localidades onde se sedeavam os tribunais distritais ${ }^{(21)}$.

Nos inícios do século XVII, as visitas inquisitoriais e a publicação dos éditos da fé, anualmente lidos e afixados às portas das igrejas paroquiais, eram os mecanismos nos quais o Tribunal do Santo Ofício confiava para obter a maioria das denúncias que acabavam por gerar os

(21) Não abundam na historiografia portuguesa estudos centrados sobre a dinâmica de entradas inquisitoriais numa dada localidade que permitam entender melhor, não só esse processo concreto, mas também a forma como a instituição marcou a vida comunitária e ainda o modo como foi usada por certos grupos e indivíduos na defesa dos seus interesses e estratégias. Uma excelente abordagem, nesta perspectiva, centrada sobre a actuação da Inquisição em Múrcia e em Lorca é Jaime Contreras, Sotos contra Riquelmes, Madrid, Anaya, 1992. Para o caso português, o estudo que mais se aproxima desta perspectiva, mas avaliando o espaço de uma "região" e não de uma localidade, se bem que na prática a sua maior incidência recaia sobre Faro (ver tabela apresentada na p. 28) é Joaquim Romero Magalhães, "E assim se abriu judaismo no Algarve", Revista da Universidade de Coimbra, vol. XXIX, 1981, pp. 1-74. 
processos que instituía, com o escopo de proteger a pureza da fé e a ortodoxia religiosa. Contava-se ainda com a cooperação da justiça episcopal(22), que remetia os casos de seu conhecimento que "tocavam" heresia, mas o número de processos intentados a partir desta origem não seria muito elevado. Mais tarde, sensivelmente a partir do derradeiro quartel do século XVII, a criação de uma densa rede de comissários e familiares, assegurará a eficácia do controle das populações a nível local e servirá como veículo de alimento dos "cadernos do promotor", nos quais se arquivavam as denúncias que chegavam ao tribunal ${ }^{(23)}$. Assim, sobretudo numa primeira fase, era necessário que a nível local houvesse algo que fizesse disparar todo o processo. Ou seja, a partir da estrutura centralizada que assentava nos três tribunais distritais de Coimbra, Évora e Lisboa, a que se juntava $\mathrm{Goa}^{(24)}$, a instituição fazia difundir uma mensagem em que apelava à denúncia de heresias, mas não podia iniciar qualquer acção antes de possuir acusações concretas. A existência de um detonador local era, por conseguinte, imprescindível ${ }^{(25)}$.

(22) Sobre as relações de cooperação entre o poder episcopal e inquisitorial ver José Pedro Paiva, "Os bispos e a Inquisição portuguesa (1536-1613)", Lusitania Sacra, $2^{\text {a }}$ série, vol. XV, 2003, p. 43-76.

(23) Sobre o crescimento vigoroso dos "quadros burocráticos inquisitoriais" a partir de 1670-1720, ver José Veiga Torres, "Da repressão religiosa para a promoção social. A Inquisição como instância legitimadora da promoção social da burguesia mercantil", Revista Crítica de Ciências Sociais, vol. 40, 1994, pp. 130-131. Apesar de Veiga Torres demonstrar que o crescimento de familiares foi acompanhado de uma significativa redução do número de processos instaurados pelo Tribunal, o que o levou a defender a tese de que, a partir deste ciclo, a instituição se foi transformando de instância de repressão em instrumento de promoção social, uma análise atenta dos "cadernos do promotor" evidencia que este crescimento de comissários locais foi acompanhado por uma autêntica "explosão" do número de denúncias que chegavam ao Tribunal.

(24) Neste último caso é de admitir uma especificidade distinta, em função do contexto espacial e cultural da sua inserção. Ainda que reportando-se a uma época posterior à que aqui se trata ver Maria de Jesus dos Mártires Lopes, "A Inquisição de Goa na primeira metade de Setecentos uma visita pelo seu interior", Mare Liberum, vol. 15, 1998, pp. 107-136.

(25) Tal constatação pode verificar-se também no caso do Algarve, onde o bispo D. Francisco de Meneses, que anteriormente tinha sido inquisidor, desempenhou esse papel, como o mostra exemplarmente Joaquim Romero Magalhães, "E assim se abriu judaismo no Algarve", ob. cit., pp. 7-9 e 16. 
No caso da primeira entrada em Melo há abundantes evidências de que tudo foi desencadeado pela acção do prior e comissário do Santo Ofício, padre António Feio da Orta ${ }^{(26)}$. Múltiplos aspectos o demonstram.

As primeiras denúncias contra cristãos-novos de Melo, que estiveram na origem das cinco primeiras prisões, feitas em Maio de 1601, foram efectuadas por um António Manuel, cristão-velho, de 35 anos, cardador e criado de um dos acusados, que dava pelo nome de Gaspar Lopes. No dia quatro de Janeiro de 1600, quase um ano e meio antes das primeiras detenções, o que mostra os cuidados com que tudo se preparava, ele deslocou-se de Melo até à Mesa da Inquisição de Coimbra para declarar que, quatro anos antes, tendo estabelecido um contrato com Diogo Fernandes, mercador de panos, para "lhe cardar lã e trabalhar em um tinte", fora residir para sua casa. Nessa condição viu que três das filhas do seu patrão que trabalhavam na roda de fiar, o faziam quotidianamente, excepto aos sábados. Mais, que Diogo Fernandes e toda a família, aos sábados, vestiam camisas lavadas e que a sua mulher e as filhas cozinhavam os alimentos que se consumiam no sábado, na sexta-feira anterior, pelo que, no dia ulterior, quando davam a comida aos seus trabalhadores, apenas a aqueciam ao lume. Além disto, as raparigas, às sextas-feiras, limpavam as candeias e punham-lhes torcidas novas, deixando-as acesas até à manhã seguinte. Acrescenta ainda que na casa de Gaspar Lopes, cunhado de Diogo Fernandes, seu patrão ao tempo em que fez estas denúncias, também era costume ninguém trabalhar aos sábados, quando matavam algum carneiro nunca aproveitavam o seu sangue, derramando-o pelo chão ou dando-o, e não comiam carne de porco, nem peixe sem escama. Neste depoimento, repleto de referências a um conjunto de cerimónias que sempre formaram a base habitual das

(26) Não disponho de informações precisas mas, pelo menos desde 1596, que exercia as funções de prior de Melo, benefício que era da apresentação dos senhores de Melo. A posse do priorado pode confirmar-se com o depoimento de uma testemunha de acusação, ver IAN/TT, Inquisição de Coimbra, processo 886, fl. 6-6v. O padroado da casa de Melo em relação à freguesia do mesmo nome, bem como às circunvizinhas de Arcozelo, Freixo da Serra, Vila Franca, Cortes da Serra, Nabais e Nabainhos, pode comprovar-se pelas informações de Paulo Dias Niza, Portugal Sacro-profano...., Lisboa, Officina de Miguel Manescal da Costa, 1767, vol. II, p. 10 (para Melo). 
acusações contra cristãos-novos judaizantes ${ }^{(2 \pi)}$, confessa ainda que a sua vinda à Mesa fora provocada pelo facto de se ter ido confessar ao prior de Melo, padre António Feio da Orta, e este lhe ter comunicado que devia denunciar estes episódios ao Santo Ofício, justificando ainda a demora com que o fez, por ser pobre e não ter meios para vir até à cidade ${ }^{(28)}$.

Poucos meses depois, em 12 Maio de 1600, Alexandre Feio, sobrinho do padre António Feio, na altura com 18 anos de idade e estudante de latim no Colégio das Artes, em Coimbra, apareceu na Mesa para dizer que cerca de um ano antes, estando ele em Melo, no quintal de Diogo Fernandes, viu degolarem um carneiro e não aproveitarem o sangue, sendo ainda costume que na casa dele ninguém trabalhasse ao sábado ${ }^{(29)}$.

Finalmente, em três de Agosto de 1600, foi a vez de o próprio padre António Feio ter ido à Mesa da Inquisição de Coimbra dizer que, morando três anos em frente da casa de Gaspar Lopes, via que toda a gente "guardava os sábados", sendo que em todos os outros dias "trabalhavam com muita diligencia, levantando-se muito cedo", de forma que até o incomodavam com o tráfego que faziam a levar panos e a aparelhar as suas cavalgaduras. Acrescenta ainda que nunca os vira comer carne de porco nem peixe sem escama ${ }^{(30)}$.

Baseados nestas três acusações ordenaram os inquisidores que se fizesse uma "comissão" para ir ouvir testemunhas a Melo. Foram então ouvidas três pessoas, todas cristãs-velhas, que confirmaram o sentido geral do que estas delações haviam indiciado. Foi esta a base da "leva" das cinco primeiras prisões.

Outros indícios colocam o prior de Melo como epicentro de todas as movimentações. O padre António Feio foi o autor da detenção dos dezasseis réus que constituíram a segunda e maior "leva" de capturas, todos

(27) Vejam-se as práticas criptojudaicas já elencadas num monitório de 1536, referido por Francisco Bethencourt, "Rejeições e polémicas", in Carlos Moreira Azevedo (Dir.), História Religiosa de Portugal, Lisboa, Círculo de Leitores, 2000, vol. II, pp. 59-60 e o ajustadíssimo comertário que aí profere quando constata que o monitório elenca mais as práticas do que as crenças "como se o juiz percebesse que seria mais fácil obter confissões ou denúncias a partir das práticas do que a partir de um núcleo de crenças naturalmente mais íntimo e difícil de penetrar".

(28) Ver IAN/TT, Inquisição de Coimbra, processo $\mathrm{n}^{\circ} 886$, fl. $5-7 \mathrm{v}$.

(29) Ver IAN/TT, Inquisição de Coimbra, processo n ${ }^{\circ}$ 7618, fl. 5-6.

(30) Cf. IAN/TT, Inquisição de Coimbra, processo $n^{\circ}$ 886, fl. 8 ss. 
entrados nos cárceres de Coimbra em 10 de Agosto de 1602. O próprio o refere, não escondendo algum orgulho no facto, em carta que remete para Coimbra, escrita pelo seu punho, dois dias antes. Nessa missiva, não só se queixa de um familiar do Santo Ofício que pela sua desajeitada intervenção teria provocado a fuga de muitos cristãos-novos ${ }^{(31)}$, como apresenta esta leva de presos como "o maior laço que nunca se vio por estas partes", denotando uma perfeita consciência da aç̧ão que se estava a empreender, e revela ainda o modo como tudo se processou e o alvoroço que tudo causou. Nas suas palavras: "vendo ao domingo que homem nem molher entrava para a Igreja aonde tinha assentado fazer meo officio, senão este Rui Teles, entrei e o prendemos e logo o juiz, com meus sobrinhos e eu tremendo com toda a vila que nos acompanhou, com muita diligencia e vontade, demos por essas casas. E huma tiramos de huma arqua, outra de hum palheiro, e não podemos coalhar mais que essas dezaseis pessoas, o que taobem atribuo a pecados meos. Os fogidos nao foram buscados [...]. Os mais que não tinha na lista taobem com medo fogirão, se tornarem trabalharei por emendar o perdido"(32).

Note-se ainda que, depois do perdão geral de 1605, que suspendeu a acção que se fazia em Melo, tendo dele beneficiado 26 pessoas, todo o processo foi de novo reiniciado a partir das acusações de um sobrinho de António Feio, originando que a Inquisição fizesse novo "sumário de testemunhas", base de uma série de prisões efectuadas em 6 de Março de $1607^{(33)}$.

Por último, no que concerne à demonstração do envolvimento do prior António Feio da Orta como desencadeador deste movimento, é fundamental referir como toda a comunidade tinha consciência do papel que ele desempenhara. De facto, não só há bastantes réus que apresentam "contraditas" contra ele, como, e de um certo modo mais exemplarmente, se conhecem outros documentos que faz todo o sentido revelar neste contexto. O primeiro é uma carta da própria vereação de Melo, dirigida à Inquisição de Lisboa, eventualmente com receio de que a influência

(31) Como escreve o prior, haver familiar do Santo Oficio "não foi obra de Deus senão obra do demonio para impedir as obras de Deus".

(32) Cf. IAN/TT, Inquisição de Coimbra, Cadernos do Promotor, Livro $\mathrm{n}^{\circ} 290$, fl. 250-50v.

(33) Ver, por exemplo, IAN/TT, Inquisição de Coimbra, processos n 201 e 2588, fl. não numerado (primeiras acusações e "sumário de testemunhas"). 
do prior em Coimbra pudesse abafar os queixumes que se relatavam. Nela, em 10 de Fevereiro de 1608, os membros da vereação reclamam que os negócios do Santo Ofício não fossem cometidos a pessoa de "tão má condição", como era o doutor António Feio da Orta, elencando de seguida um amplo rol dos seus despropósitos. Que na estação da missa fazia pregações infamando com nomes afrontosos muita gente da terra; que fazendo diligências de prisão ordenadas pela Inquisição as executava com muitos excessos "no pino da noite", "arrombando portas" e com "pistoletes na mão"; que tomava para si "porcelanas, moveis e chapeus" que estavam nas casas dos cristãos-novos que prendia; que tinha tanto ódio aos irmãos da Misericórdia que se demitiu da Confraria e não ia às procissões por ela organizadas; que pelo seu procedimento o bispo de Coimbra depois de o haver nomeado para visitador de um arcediagado o destituíra dessa função ${ }^{(34)}$. Carta que deixa entender como a influência, senão presença, dos cristãos-novos se havia infiltrado na vereação local. Sublinhe-se que, quando os inquisidores de Lisboa mandam esta carta para Coimbra, sugerem que se façam investigações e não se confiem mais incumbências ao prior. E, de facto, quando em 10 de Dezembro de 1609 se foram ouvir testemunhas solicitadas pelo marido de uma Clara da Silva, o comissário já não foi o prior, mas sim o clérigo de missa de Melo, Francisco Gomes ${ }^{(35)}$.

O segundo documento, ainda mais contundente, é um conjunto de queixas destinado a ser entregue ao visitador do bispo, assinado por cerca de 40 pessoas de Melo, entre os quais muitos cristãos-velhos. Nele se requeria que o visitador indagasse, entre outras coisas, se era verdade que o prior ensinava doutrina; se cobrava três mil réis pelo enterro dos defuntos pobres; se na esţação da missa desonrava com palavras infames os fregueses, chamando a uns "vilaos roins", a outros "ladroes" e a outros "judeus e caes"; se proferira na missa que havia "sessenta cornudos" em Melo, o que muito escandalizara o povo; se não intrigava de uns contra os outros trazendo "a terra toda baralhada"; se indo duas mulheres comungar ele as mandara levantar dizendo que não administrava o Santíssimo "a putas"; se em certa noite de Natal espancou um rapaz e depois foi

(34) Ver IAN/TT, Inquisição de Coimbra, Cadernos do Promotor, Livro n 290, fl. 466-67.

(35) Ver IAN/TT, Inquisição de Coimbra, processos n 2589, fl. 31 ss. 
dizer a missa do galo; se disse na missa que quem quisesse "testemunhas de meio tostão" fosse ter com ele e que de todo o preço as daria, etc ${ }^{(36)}$.

Enfim, parece claro que a guerra local contra alguns cristãos-novos que o prior de Melo abrira, acabou por lhe trazer problemas a si, indiciando ainda résteas da influência de que os cristãos-novos haviam usufruído.

Quanto às contraditas elas são de igual modo sumamente esclarecedoras de como muitos dos processados tinham consciência de que tudo fora desencadeado pelo prior de Melo. Assim, um Pedro Fernandes, por exemplo, procurou demonstrar como ele ficara seu capital inimigo após discórdias com uma D. Maria de Melo. Esta senhora tinha um pregador para lhe dizer missas e pregar na igreja de Melo. Em dada altura, o prior disso a impediu, pelo que ela o delatou, apresentando o Pedro Fernandes e muitos cristãos-novos como testemunhas. Por isto o prior ficara com ódio a todos, "tanto que muitos dias na igreja os ameaçava que os avia de fazer vir à Inquisição" (37). Por sua vez, Brites Gomes, dizia que o prior era seu inimigo porque andara amancebado com uma mulher da terra e ela o seu marido denunciaram-no ${ }^{(38)}$. Há mesmo quem sustente, como foi o caso de um cristão-velho casado com uma Clara da Silva, cristã-nova, que um sobrinho do padre dizia publicamente que o prior de Melo "faria judeo quem quisesse" e que o ódio que lhe tinha a ele nascera do facto de em tempos, sendo ele vereador, ter ido prender um rapaz criado de um tio do prior, para ele ir servir como soldado ${ }^{(39)}$.

Todos estes e outros relatos de contraditas, comprovados por testemunhos, têm o condão de mostrar que os motivos que levariam às denúncias a nível local não eram exactamente os mesmos que faziam actuar os inquisidores: a extinção de heresias. As motivações locais tinham na maior parte das vezes fundamento em discórdias de todo o género entre pessoas que tinham uma vida comunitária muito próxima e intensa (dívidas não saldadas, empréstimos recusados, questões de fl. 468-69.

(36) Cf. IAN/TT, Inquisição de Coimbra, Cadernos do Promotor, Livro $\mathrm{n}^{\circ} 290$,

(37) Cf. IAN/TT, Inquisição de Coimbra, processo $n^{\circ} 2396$, fl. 24 ss. Note-se que muitas das testemunhas de contraditas confirmam este depoimento do réu.

(38) Cf. IAN/TT, Inquisição de Coimbra, processo $n^{\circ} 8037$, fl. não numerado da apresentação de contraditas.

(39) Cf. IAN/TT, Inquisição de Coimbra, processo n 2589, fl. 14. 
honra, desentendimentos em negócios, quezílias familiares, problemas causados por águas de rega, animais que invadiam e destruíam a propriedade alheia, etc.) e ainda desejos de obtenção de mais valias materiais por parte dos que previam que o confisco de certos bens dos réus podiam vir a ser adquiridos por si.

Neste contexto, não se pode deixar passar em claro um comentário produzido pelo prior de Melo, em carta de Fevereiro de 1602, dirigida aos inquisidores de Coimbra: "se eu podera passar os limites da minha vista nao fogira Francisco Nunes de Linhares, que foi a maior perda que podia aver nestas vilas, asim pera ser principio de se entrar em Linhares como por se perderem quinze mil cruzados que tem de seo" ${ }^{\prime(40)}$. A acusação ao Santo Ofício constituía, então, um meio que podia servir outros fins, o que não implica que as acusações fossem infundadas. Mas não era, todavia, o seu conteúdo, que na maioria das vezes preocupava e fazia agir os delatores. No caso de Melo podem inventariar-se múltiplos motivos que ajudam a perceber o alvo de certas denúncias, sem que se possa constatar qualquer padrão uniforme, ou existência de facções. As motivações tinham raiz individual.

No caso da segunda entrada, e apesar de algumas dificuldades na reconstituição dos seus primeiros momentos, por não ser já possível a leitura do primeiro processo que a marcou, isto é, o de Gaspar Rodrigues Frois ${ }^{(41)}$, tudo aponta para um detonador diferente. Desta vez foi uma denúncia de um residente em Guimarães, que tinha familiares em Melo, a que se adicionou a memória que na instituição se guardava da entrada dos inícios do século, que colocou a máquina a funcionar ${ }^{(42)}$.

(40) IAN/TT, Inquisição de Coimbra, Cadernos do Promotor, Livro n 290, fl. 249.

(41) Solicitei autorização pessoal e expressa à responsável por este fundo documental no IAN/TT, na altura a Ex.ma Senhora Dr. ${ }^{a}$ Maria do Carmo Dias Farinha, para ver este e outros processos que eram dados como estando em mau estado. Não obtive, todavia, essa permissão, com base no argumento de que os documentos, devido ao seu estado de conservação, estavam já ilegíveis, aspecto que, obviamente, não posso comprovar. Espero que o zelo de competentes arquivistas não se torne um elemento bloqueador da única utilidade dos documentos. É que estes documentos só tem valor e préstimo se forem utilizados pelos historiadores e estudiosos do passado. Jacentes num arquivo transformado em esconderijo são de total inutilidade.

(42) Mostra-o a prisão de Francisca Pinheiro, mulher do tal Gaspar Rodrigues Frois, ver IAN/TT, Inquisição de Coimbra, processo nº 4297. 
Desencadeado o movimento, e pesem as múltiplas estratégias que os réus individualmente seguiam, como a seu tempo se mostrará, havia toda uma lógica interna de funcionamento do processo inquisitorial que se encarregava de ir auto-alimentando estas incursões numa determinada localidade. Assim foi em Melo, onde as confissões daqueles que iam sendo detidos forneciam as indicações de que os inquisidores necessitavam para ir continuando a perseguição. Por exemplo, a base para a captura dos dezasseis cristãos-novos presos em 1602 foram acusações, por vezes de testemunhos singulares, dos cinco réus que tinham sido presos em $1601^{(43)}$. É que, como já foi bem salientado, por exemplo por Lúcio de Azevedo, os inquisidores estimulavam novas denúncias, pois "bom penitente" era aqule que "descobria" outros culpados ${ }^{(44)}$. Aliás, o próprio Regimento da Inquisição, em 1613, colocará este princípio em letra de forma, assumindo um procedimento que já anteriormente se praticava: "He grande sinal do penitente fazer boa confissão, \& verdadeira, descubrir outros culpados dos mesmos errores, especialmente sendo pessoas chegadas \& conjuntas em sangue, \& a que tenham particular affeição" ${ }^{\prime(45)}$. Note-se, todavia, que este entendimento não pretende significar, como sugere António José Saraiva, que a maior parte das denúncias eram falsas e instigadas por ódios e inimizades ${ }^{(46)}$. Antes constata um aspecto concreto ligado ao processo inquisitorial e à própria acusação de judaísmo, que como religião presumia práticas comuns, logo cúmplices ${ }^{(47)}$.

(43) Vejam-se por exemplo, os processos de Ana Dias (IAN/TT - Inquisição de Coimbra, processo $\mathrm{n}^{\circ}$ 892), Genebra Gomes (IAN/TT - Inquisição de Coimbra, processo $\mathrm{n}^{\circ}$ 7308), André Gomes (IAN/TT - Inquisição de Coimbra, processo $\mathrm{n}^{\circ}$ 906), Isabel do Campo (IAN/TT - Inquisição de Coimbra, processo $n^{\circ} 7306$ ).

(44) Cf. J. Lúcio de Azevedo, História dos cristãos-novos portugueses, ob. cit., p. 135.

(45) Cf. Regimento do Santo Officio da Inquisiçam dos Reynos de Portugal, Lisboa, Inquisição de Lisboa por Pedro Crasbeeck, 1613, Título III, capítulo II, p. 5.

(46) Ver António José Saraiva, Inquisição e cristãos-novos, Lisboa, Editorial Estampa, 1985, pp. 57-60.

(47) Era semelhante o que se passava com os casos de mulheres acusadas de práticas mágicas envolvendo a presença em assembleias de bruxas (sabats), apesar de nestas matérias os inquisidores não terem sido, por norma, tão pressionantes como com os cristãos-novos. Sobre o assunto ver José Pedro Paiva, Bruxaria e superstição num país sem "caça às bruxas": 1600-1774, Lisboa, Editorial Notícias, 1997, pp. 154-159. 
E pese o facto de nalguns casos se notarem resistências em denunciar familiares próximos, por exemplo é visível que algumas mães eram particularmente renitentes em acusar os filhos, principalmente os mais pequenos ${ }^{(48)}$, na prática todos acabavam por "dar em todos", para usar expressão do tempo. Filhos acusavam os pais, estes os descendentes, maridos as mulheres e vice-versa.

Se, como se procurou mostrar, uma entrada era iniciada com um sinal dado localmente, ou talvez melhor, um sinal dado do exterior do tribunal distrital da Inquisição, que depois se ia auto-alimentando em função das próprias características do processo inquisitorial e do delito concreto de judaísmo, o seu termo era determinado pelos inquisidores. Ou seja, a partir da avaliação que iam fazendo dos processos e das denúncias que lhes chegavam, atingia-se um ponto em que os próprios inquisidores consideravam que uma "rede" local de cristãos-novos ficava desmantelada e que já não havia indícios que justificassem a prossecução de novas acções. Isso fica bem evidente quando, por exemplo, na sentença final do processo de uma Antónia do Campo, em Agosto de 1604, após terem prendido cerca de 43 pessoas e de terem listas com muitos outros cristãos-novos de Melo que haviam fugido, e justificando ainda porque não fazia sentido submeter a ré a tortura, decidem: "visto (a ré) asentar na crença e satisfazer ao principal dos autos fosse reconciliada a uniao e reconciliaçao da santa madre Igreja com carcere e habito penitencial a arbitrio dos Inquisidores dilatado; e por ser muito enferma e de pouca sustancia pareceo que nao hera capaz de algua outra diligencia, mormente sendo da vila de Mello onde tudo estava ja descuberto" (49). Não fora o perdão geral de 1605, que libertou muitos e suspendeu as penas de outros e a primeira entrada talvez tivesse terminado alguns anos mais cedo em Melo.

Uma vez presos, apesar do constrangimento da regulamentação inquisitorial e da habitual superioridade sócio-cultural dos inquisidores face aos processados, nem todos os réus usavam as mesmas estratégias

(48) Veja-se, por exemplo, o processo de uma Guiomar Gomes que foi presa conjuntamente com duas filhas e que vai denunciando muitos familiares mas poupando sempre as filhas. Acabará por o fazer, mas ocultou sempre um filho menor, de 14 anos, pelo que foi posta a tormento, onde acabou por o "descobrir", cf. IAN/TT, Inquisição de Coimbra, processo $\mathrm{n}^{\circ} 7618$.

(49) Cf. IAN/TT, Inquisição de Coimbra, processo $n^{\circ} 6545$, fl. não numerado (acórdão final dos inquisidores), itálico meu. 
de defesa. Constata-se uma pluralidade de situações, dependentes de variados factores que nem sempre se podem controlar em absoluto e que interpretações mais singelas escondem. Quer ao pretenderem que a maior parte das acusações e confissões eram falsas, baseadas em intrigas e no medo, e que os inquisidores tinham um con: rolo total sobre as respostas dos réus ${ }^{(50)}$. Quer vendo as vítimas da Inquisição como uma espécie de mártires do judaísmo (os marranos) e logo a maioria das confissões de cristãos-novos ante os juízes como relatos fiéis, de uma veracidade indiscutível, certificadores da existência de um criptojudaísmo português ${ }^{(51)}$.

Assim, sem pretender esgotar este imbrincado problema, e sem tentar decifrar quando é que os réus estavam a ser sinceros ou a produzir depoimentos falsos, caminho, em grande parte dos casos, muito difícil, se não mesmo impossível de prosseguir com êxito, em Melo encontramse as seguintes situações:

a) Indivíduos que negam todas as acusações, que apresentam defesa sustentando terem sempre sido bons cristãos, que propõem contraditas tentando inventariar todos aqueles com quem tiveram problemas, pretendendo dessa forma anular a validade dos depoimentos de acusação. Caminho deveras arriscado e que, se prosseguido até ao fim, originaria normalmente uma sentença de "relaxamento ao braço secular" por "negativo". Foi o que aconteceu com uma Antónia do Campo, que nem mesmo no tormento confessou, a não ser uns jejuns e a guarda dos sábados, o que dizia fazer não como cerimónias judaicas, mas sim cristãs, pelo que acabou relaxada, em 1608, por convicta e revogante ${ }^{(52)}$.

b) Indivíduos que negam todas as acusações que sobre eles impendiam mas que, após longos períodos de encarceramento, ou ante a ameaça do tormento, ou durante a sua execução, não resistem e decidem fazer copiosas confissões. Foi esse, por exemplo, o caso de Leonor Nunes, que saiu no auto de 1669. Esta ré sempre negou todas as acusações de que foi vítima, apresentou defesa, na qual testemunhas cristãs-velhas

(50) Ver António José Saraiva, Inquisição e cristãos-novos, ob. cit., p. 76 e 121-126.

(51) Ver I. S. Révah, "Les marranes portugais et l'Inquisition au XVIe siècle", in Études portugaises, Paris, Fundação Calouste Gulbenkian, 1975, em especial pp. 221-26.

(52) Cf. IAN/TT, Inquisição de Coimbra, processo n ${ }^{\circ} 201$. 
confirmam que ela ia à missa, se confessava e fazia as "obras dos cristãos" e, por fim, construiu uma peça de "contraditas" na qual procura acertar em todas as pessoas que ela presumia a tinham acusado. Uns tios e amigos do pai por terem problemas nos negócios, a mulher de um tosador porque o pai dela não mandava tosar os panos dele a esse tosador, uma Joana Mendes porque a mãe tinha um assento de "taboado" na igreja de Melo, que já vinha de seus antepassados, e esta Joana tirou-lho, o que foi causa de pelejas. Mas, o mais interessante, é que diz que todos os "de sua casa", pai, mãe e irmãs eram seus inimigos. O pai porque era "falho do juízo" e a perseguia a ela e aos irmãos com espadas. A mãe porque gastava exageradamente "pois queria trazer os filhos com grandes brios" e por ela a repreender ficara sua inimiga. Uma irmã mais nova, porque andava sempre a "mexericar" com a mãe e sendo mais nova queria mandar mais do que ela. $\mathrm{O}$ irmão era inimigo dela por ela lhe recusar dinheiro para jogar e "para outras coisas piores". Mais tarde, pressionada pelos inquisidores, acabou por reconhecer muitas culpas ${ }^{(53)}$.

c) Indivíduos que tendo plena consciência de que só uma confissão total e a denúncia de muitos cúmplices os libertaria, apesar de isso implicar a perca da fazenda e uma abjuração em forma, desde o início reconhecem culpas, delas pedem perdão mostrando arrependimento e "dão" o maior número possível de cúmplices. Tal se passou, por exemplo, com Isabel do Campo, saída em auto de 1602. Esta ré prontificou-se a fazer confissões logo na primeira sessão perante os inquisidores e não mais se calou no decurso da sua detenção. A sua estratégia de denúncia, perpetuou-se mesmo depois do auto-da-fé em que abjurou em forma e saiu condenada em hábito penitencial e cárcere a arbítrio dos inquisidores. Assim, dias depoiş ainda foi à Mesa delatar mais duas primas, dizendo que num dia de Endoenças, estando todas juntas, ela as convidara para irem comer um pouco de sável e raia cozidos, o que elas recusaram, alegando que a raia não tinha escamas e o sável não o comeriam por ter sido cozido junto com a raia. Talvez isso tenha contribuído para que, cerca de um mês depois, os inquisidores a tivessem mandado regressar à sua terra e suspendido a obrigação de endossar o infamante hábito de penitente ${ }^{(54)}$.

(53) Cf. IAN/TT, Inquisição de Coimbra, processo ${ }^{\circ} 7045$.

(54) Cf. IAN/TT, Inquisição de Coimbra, processo $\mathrm{n}^{\circ} 7306$. 
d) Indivíduos que vão procurando satisfazer a avidez de confissões e denúncias dos inquisidores gradualmente, tentando não deixar de fora nada nem ninguém que os pudesse fazer perigar como confessores "diminutos" e, em simultâneo, "poupar" alguns familiares. É disso exemplo Maria Lopes que saiu no auto de 1602. Esta ré, na primeira sessão de confissão, negou tudo de que era acusada. Na segunda, afirmou que pediu audiência "alumiada pelo espirito santo" para confessar suas culpas, contando apenas que no Inverno anterior, indo só com uma vizinha, ela lhe ensinou que devia fazer certos jejuns e que não comesse toucinho, para salvação da sua alma. Na terceira sessão, acrescentou que sete meses antes confidenciara que fazia estes jejuns a uma irmã e ela também os começara a praticar. Em simultâneo, procurou proteger a mãe, afiançando que quando lhe contou que ela fazia tais actos, ela lhe aconselhara que os não fizesse por serem tudo "humas feitiçarias". E assim foi paulatinamente continuando, no decurso de várias sessões, até que, ao ser ameaçada de que ia ser posta no tormento, denunciou trinta e quatro pessoas com quem teria comunicado a lei judaica ${ }^{(55)}$.

e) Indivíduos que negam tudo, se defendem e resistem ao próprio tormento o que, caso as provas contra si não fossem grandes e tivessem contraditas aceitáveis, os podia poupar de condenação severa. Tal sucedeu com Miguel da Costa, que saiu no auto de 1673, apenas condenado a abjurar de leve suspeita na fé depois de ter resistido a meia hora de polé(56).

f) Indivíduos que antecipam a aç̧ão da própria Inquisição e se apresentam ao Tribunal, arrependidos, confessando culpas e denunciando parceiros, o que lhes podia evitar o confisco de bens. Estratégia mais recorrentemente usada na segunda entrada em Melo do que na primeira, o que pode denotar um maior conhecimento do funcionamento da instituição à medida que o tempo vai passando. Veja-se, por exemplo, o caso de um Francisco Mendes Pinheiro, que se apresentou, confessou culpas e denunciou uma série de familiares próximos, como a mãe. Apesar disso, neste caso, a apresentação não o isentou do confisco de bens ${ }^{(57)}$.

g) E até indivíduos, em Melo apenas um caso, que com um certo "espírito de martírio", desde o princípio reconhecem que são judeus, que acreditam na "lei de Moisés" e nela declaram querer morrer. Nesta

(55) Cf. IAN/TT, Inquisição de Coimbra, processo $\mathrm{n}^{\circ} 886$.

(56) Cf. IAN/TT, Inquisição de Coimbra, processo n ${ }^{\circ} 4756$.

(57) Cf. IAN/TT, Inquisição de Coimbra, processo n ${ }^{\circ} 9206$. 
senda persistiu uma Clara Pinheiro, sentenciada no ano de 1669, que logo na primeira sessão com os inquisidores não teve qualquer rebuço em sustentar: "que nao tinha culpas que confessar porque nao tinha por culpa o crer na ley de Moises na qual cre de presente e determina crer enquanto lhe durar a vida como verdadeira judia e observante que he da dita lei de Moises". É um processo interessantíssimo este, pois os inquisidores tudo tentaram para a convencer de que ela seguia uma crença errada. Argumentaram que ela era uma mulher rústica que só sabia "das coisas da casa", e que por isso devia seguir os argumentos que eles lhe expunham para se querer converter ao cristianismo(58). Perguntaram-lhe se ela sabia os perigos que corria ao persistir na crença, ao que ela desassombradamente responde que entendia "muito bem que a mandarão queimar viva por crer na lei de Moyses, mas que sem embargo disso quer padecer o ditto genero de morte, por entender que so crendo na dita ley pode salvar sua alma, por causa de cuja salvação faz pouco caso de perder a vida". Mandam-lhe ao cárcere lentes de teologia, jesuítas e um cónego regular de Santo Agostinho, para lhe mostrarem os erros que perfilhava. Nada a convencia. Mas as insistências foram tantas que, um ano após as primeiras sessões que com ela se tiveram, pediu mesa, $e$ "sendo presente com muitas lagrimas e soluços e mostras de arrependimento posta de joelhos diante do altar em que no oratorio esta a imagem de Christo nosso senhor crucificado fez uma protestação da fe e disse que alumiada pello Espirito Santo, com a lembrança das admoestações e repetidas diligencias que com ella se haviam feito nesta Mesa, de todo o coração vinha reduzirse a nossa santa fe catholica a apartarse da crença na ley de Moyses na qual athe ontem a tarde havia firmemente crido..." ${ }^{(59)}$."

(58) Veja-se o sugestivo enunciado da primeira questão que lhe colocam após ela ter confessado a crença de que salvaria a alma seguindo a lei judaica: "Perguntada que razao tem ella declarante sendo huma mulherzinha simples, sem letras, lição, ou sciencia alguma, e que so sabia o que tocava ao trato de sua casa de portas adentro, para nao se aconselhar com pessoas doutas em materia de tanta importancia e tão grave como he a de sua salvação...", cf. IAN/TT, Inquisição de Coimbra, processo $\mathrm{n}^{\circ} 5735$, fl. 39.

(59) Cf. IAN/TT, Inquisição de Coimbra, processo $\mathrm{n}^{\circ} 5735$, especialmente fólios $5-14,19,40 v ., 48-49 v$ e 106. 
Em suma, sete vias diferentes que parecem ter um fito comum: sair o mais depressa possível e com o menor número de danos (físicos e materiais) viável da difícil situação em que os acusados se encontravam. Daí poder-se concluir que durante o processo nem tudo era controlado e determinado pelos inquisidores.

\section{A comunidade cristã-nova em Melo: integração, segregação e crenças}

A partir do amplo conjunto de testemunhos que se podem recolher nos processos inquisitoriais, esbocem-se agora alguns dos traços que permitem configurar a comunidade cristã-nova da pequena vila da Beira interior no século XVII.

No corpo documental considerado coligem-se 101 referências expressas a profissões/actividades de cristãos-novos ${ }^{(60)}$, que denotam como a comunidade se aproximava do padrão geral do reino, tal como foi esboçado por Maria José Ferro Tavares, quando sustentou que eram "mercadores de panos de capacidade económica média que, para além do comércio terrestre no reino e em Espanha, investiam também no arrendamento de impostos municipais, régios ou da nobreza [...]. Mas a grande maioria da população cristã-nova dedicava-se aos ofícios e ao pequeno comércio de tenda aberta ou ambulante, desenvolvendo actividades como sapateiros, ferreiros, ourives, prateiros, alfaiates, confeiteiros, trapeiros, tecelões, carniceiros, etc."(61). Em Melo, o conjunto mais significativo era o dos mercadores/tratantes, de panos ou linho, na sua quase totalidade, que constituem cerca de $36 \%$ dos casos conhecidos. Próximo deles, em termos económicos e familiares, registem-se cinco rendeiros e dois sujeitos que "viviam de sua fazenda". Seguem-se os tendeiros, com perto de $12 \%$ e os tosadores com 10\%. Depois aparece um variado rol de ofícios que se inserem no padrão acima exposto, aqui com predomínio dos ligados às actividades dos lanifícios: pisoeiros (5), tintureiros (3) e trapeiros (6). Mas há também alfaiates (2), almocreves (3), sapateiros (5) e carpinteiros

\footnotetext{
(60) Incluem-se neste quantitativo quer profissões/actividades de réus, quer de seus familiares (habitualmente os pais e os cônjuges).

(61) Cf. Maria José Ferro Tavares, "Cristãos-Novos", in Carlos Moreira Azevedo (Dir.), Dicionário de História Religiosa de Portugal, Lisboa, Círculo de Leitores, 2000, vol. II, pp. 28-29.
} 
(2). São ainda referidos um cirurgião, um feitor de alfândega e um lavrador. Ou seja, pelas actividades económicas a que se dedicavam, os cristãos-novos distinguiam-se claramente dos seus vizinhos cristãos-velhos que, esmagadoramente, viviam do trabalho da terra. Note-se que, entre os cristãos-novos, o único lavrador era, significativamente, um quarto de cristão-novo, pois o pai era cristão-velho e a mãe já era meia cristã-nova ${ }^{(62)}$.

A família como unidade económica produtiva era uma realidade importante. Por exemplo, os mercadores/tratantes tinham habitualmente filhos que os acompanhavam ou que eram também mercadores estabelecidos por si, enquanto os elementos femininos (mulher, filhas, nalguns casos irmãs solteiras), trabalhavam em casa tingindo lãs, urdindo ou fiando os produtos que depois se vendiam.

Globalmente os cristãos-novos viviam, portanto, uma situação económica segura, nalguns casos de franca prosperidade, como o comprovam as referências a "criados" que alguns possuíam ${ }^{(63)}$, os inventários de bens que declaram ao serem presos pelo Santo Ofício ${ }^{(64)}$, o facto de arrendarem casas e emprestarem dinheiro ${ }^{(65)}$, as designações com que alguns são nomeados ${ }^{(66)}$. Mas também os havia pobres, como Genebra Gomes que,

(62) Tratava-se de Fernão Gomes, ver IAN/TT, Inquisição de Coimbra, processo $\mathrm{n}^{\circ} 5129$.

(63) Por exemplo, Guiomar Gomes conta que estando a conversar com uma amiga pediu a uma criada para ir apanhar umas nozes ao seu quintal, ver IAN/TT, Inquisição de Coimbra, processo $\mathrm{n}^{\circ} 7618$, fl. não numerado (na $2^{\mathrm{a}}$ sessão de confissão).

(64) Por exemplo, uma Catarina de Cáceres declara que em Melo tinha três casas sobradas, duas térreas, uma vinha, um pomar, um "tinte que he uma logea com huma caldeira grande de cobre e outra pequena onde tingem as las e panos". Em Folgosinho possuía umas terras de pão e castanheiros. Acrescenta ter os bens móveis necessários para seu uso e de seu marido e mais alguns outros que consistiam em toalhas, guardanapos e lençóis, não lhes sabendo o número nem a valia, cf. IAN/TT, Inquisição de Coimbra, processo $\mathrm{n}^{\circ} 326, \mathrm{fl} .1$.

(65) Ver IAN/TT, Inquisição de Coimbra, processo $n^{\circ} 2602$, fl. 2 a 5. Trata-se do processo de uma Antónia Rodrigues, prestamista e proprietária de casas que alugava. Os seus inquilinos e devedores acabaram por ser algumas das testemunhas que a acusaram ao Santo Ofício.

(66) Em 23 de Setembro de 1602, os inquisidores escrevem que um Henrique Mendes era pessoa "rica e abonada", cf. IAN/TT, Inquisição de Coimbra, processo $\mathrm{n}^{\circ} 5072$, fl. não numerado. Através de um segundo processo contra o réu sabe-se que era prebendeiro de rendas do mosteiro do Lorvão, ver IAN/TT, Inquisição de Coimbra, processo $\mathrm{n}^{\circ} 6845$, fl. 37. 
vindo presa para Coimbra, mendigou esmola em Pinhanços para se poder sustentar, e um almocreve que depois trouxe uma sua filha presa, classifica-a, como "pobre"(67).

Não era fácil a integração plena dos cristãos-novos em Melo. Provocada por atavismos locais e/ou por pressões externas (acção inquisitorial, intervenção de pregadores, legislação geral do reino, etc), um clima de segregação e de separação entre os descendentes dos judeus convertidos e os cristãos era indisfarçável.

Muitos cristãos-novos usavam múltiplas estratégias para camuflar a sua origem, principalmente executando todos os gestos que eram próprios dos cristãos e tentando participar nas suas organizações. Iam à missa, e até lá possuíam bancos de destaque ${ }^{(68)}$, integravam-se nas romarias que regularmente de Melo se faziam aos lugares vizinhos de Nabainhos e Gouveia ${ }^{(69)}$, faziam-se membros das confrarias e apoiavam materialmente as suas festividades ${ }^{(70)}$, tentavam integrar a Misericórdia como seus irmãos e benfeitores, quase todos sem excepção recebiam os sacramentos da Igreja e sabiam a doutrina e os mandamentos da Lei de Deus e da Igreja ${ }^{(71)}$, colocavam filhas em conventos ${ }^{(72)}$, buscavam lugares na vereação e até havia quem tivesse o cuidado de comer carne de porco publicamente para vincar bem a impossibilidade da sua fidelidade à lei mosaica ${ }^{(73)}$.

(67) Ver, IAN/TT, Inquisição de Coimbra, processo $n^{\circ} 7328$, fl. $27-28$ e processo $\mathrm{n}^{\circ} 892$, fl. não numerado.

(68) Ver IAN/TT, Inquisição de Coimbra, processo n ${ }^{\circ} 7045$, fl. 38v.

(69) Ver IAN/TT, Inquisição de Coimbra, processo n ${ }^{\circ} 201$, fl. 18.

(70) Ver IAN/TT, Inquisição de Coimbra, processo $\mathrm{n}^{\circ} 2396$, fl. não numerado da sessão de defesa, onde o réu diz ser membro da confraria de S. Sebastião e ter gasto tudo o que pode nas festas que nesse ano se fizeram.

(71) Como o provam os interrogatórios que se lhes faziam durante os processos inquisitoriais. Em muitos casos havia até o cuidado de registar que os réus sabiam "muito bem" a doutrina, o que implicava saber persignar-se e recitar o Padre Nosso, Avé Maria, Credo, Salvé-Rainha, ver IAN/TT, Inquisição de Coimbra, processo $n^{\circ} 326$, fl. 3-7.

(72) Ver IAN/TT, Inquisição de Coimbra, processo $n^{\circ} 4756$, fl. não numerado, na sessão de genealogia, onde o réu diz que tinha quatro irmãs religiosas no mosteiro de S. Bento de Évora.

(73) Ver IAN/TT, Inquisição de Coimbra, processo $\mathrm{n}^{\circ} 201, \mathrm{fl} .17 \mathrm{v}$. 
Apesar disso, na generalidade a segregação era notória. Desde logo na própria estrutura da distribuição espacial dos moradores na vila. Se bem que em Melo haja raras notícias de cristãos-novos vizinhos "paredes-meias" dos cristãos-velhos ${ }^{(74)}$, existia uma zona da vila, onde a maioria deles residiriam, chamemos-lhe judiaria, por facilidade de expressão. A sua localização seria, provavelmente, numa área mais periférica, pois uma testemunha de contraditas, inquirida sobre a existência de brigas entre membros das duas comunidades refere, em 1608, nada saber a esse respeito, pois vivia perto do adro da igreja de Melo, onde se situava também a casa da Câmara, portanto o "centro", ou seja, "mui apartada da gente de nação e de suas ruas em que elles vivem nesta vila"(75).

Outro sintoma manifestava-se através da impossibilidade de acesso a cargos na governança local e na Misericórdia, lugares que, no século XVI, muitos cristãos-novos já tinham ocupado. Note-se que um privilégio de 1520, reinava então D. Manuel I, estabelecera que na vizinha Gouveia os cristãos-novos pudessem ser eleitos para oficiais do concelho, cargos que aí exerceram, como sucedeu também em $\mathrm{Melo}^{(76)}$. A Misericórdia também fora ponto de passagem de cristãos-novos. As Informações paroquiais de 1721, ainda registam a sepultura no templo da Misericórdia de uma Serena Mendes, falecida em 1601, mãe de um dos réus da primeira entrada da Inquisição em Melo, e de um Diogo Mendes Teles, falecido em 1592, de que há enormes probabilidades de ser parente de alguns dos perseguidos na mesma entrada ${ }^{(7)}$. Mas depois da primeira entrada estas possibilidades de aceder aos postos do poder e da distinção social local desaparecem. Isso fica bem patente no depoimento de duas testemunhas de contradita do processo de Brites Gomes. Uma, o doutor

(74) Ver, por exemplo, o caso acima referido do prior de Melo que foi vizinho de Gaspar Lopes.

(75) Cf. IAN/TT, Inquisição de Coimbra, processo $n^{\circ} 8037$, fl. não numerado, depoimentos das testemunhas de contradita.

(76) Este privilégio, registado em IAN/TT, Chancelaria de D. Manuel, Livro 44, fl. 6, está publicado em Manuel Augusto Rodrigues, "A inscrição hebraica de Gouveia", ob. cit., pp. 266-267.

(77) Serena Mendes era mãe de Henrique Mendes, réu que saiu nos autos de 1605 e de 1623. As informações paroquiais de 1721 respeitantes a Melo foram publicadas por Eduardo Mota, Corografia Setecentista do concelho de Gouveia, Gouveia, Oficina Gráfica de Gouveia, Lda, 1992, pp. 125-127. 
Francisco da Rosa, morador em Melo, dizia ser verdade "que os cristãos novos antiguamente entravão nos oficios da Republica servindo de juizes e vereadores e assi por oficiaies das confrarias do Santissimo Sacramento e Nossa Senhora e tesoureiros da Santa Misericordia mas agora não. E disse que ouvira ha muitos annos ao prior (António Feio) que enquanto elle fosse da Igreja da dita villa nunqua nenhum cristão novo seria mordomo nela do Santissimo Sacramento, e assi não servirão mais; e que quanto aos oficios da Republica, que elle testemunha nao sabe quem lhos estrova, nem por que causa deixao de servir" ${ }^{\prime \prime 8)}$. Outra testemunha, Manuel Lopes, mercador, conta dúvidas havidas na vila, entre cristãos-novos e cristãos-velhos, por causa de uma eleição para a vereação e confirma que depois que o Santo Oficio prendeu os primeiros cristãos-novos, em 1601, o provedor da Misericórdia pediu que todos os descendentes dos judeus que eram irmãos fossem riscados da irmandade, o que foi feito.

A tendência para a endogamia é outro sinal das dificuldades de junção das duas comunidades. De facto, a maioria dos cristãos-novos casavam entre si, muitas vezes agregando duas famílias através do matrimónio de vários irmãos e irmãs. Assim sucedeu, por exemplo, com duas das familias que foram praticamente dizimadas durante a primeira entrada da Inquisição em Melo: os "Gomes" e os "Fernandes", estes originários de Trancoso, mas ao casarem indo residir para Melo. Entre eles celebraram-se quatro casamentos, como se pode observar no esquema representado na figura número um.

(78) Cf. IAN/TT, Inquisição de Coimbra, processo $n^{\circ}$ 8037, fl. não numerado, depoimentos das testemunhas de contradita. 


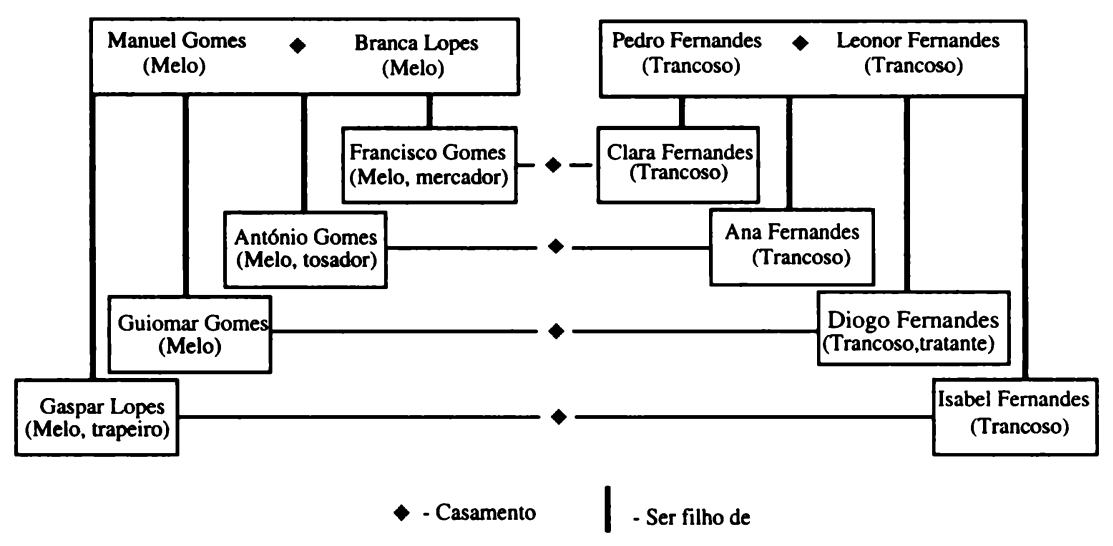

Figura $n^{\circ}$ 1: Endogamia entre familias cristãs-novas

É claro que existiam "casamentos mistos", que podem até ser interpretados como estratégias de integração e de tentativa de diluição de um estigma, como outras que já se elencaram. Entre o grupo que aqui se considera registaram-se apenas quatro. Três em que o elemento feminino do casal era cristão-novo e apenas um em que essa era a condição do elemento masculino. Mas estas uniões implicavam riscos. Um era o da possibilidade da desagregação da família em virtude da acção inquisitorial. O outro eram as represálias dos próprios cristãos-novos sobre os seus congéneres que seguiam este caminho.

É disso paradigma o caso de uma Clara da Silva, igualmente bom exemplo de como a Inquisição também era usada como instrumento de "ajuste de contas" entre pessoas desavindas. Contemos resumidamente a história. Clara da Silva, era meia cristã-nova, pois o seu pai era um tratante de panos, de Celorico da Beira, e a mãe era uma cristã-velha de Melo. Clara, nasceu em Melo e aí casou, com um cristão-velho, António Fernandes. O seu processo inquisitorial espanta pelo empenho do marido na sua defesa. Ela fora acusada por uma única testemunha, sua prima, que desvelou as suas supostas e vagas crenças na "lei de Moisés". Dois dias após a sua prisão, o marido, pesaroso, escreve uma carta para os inquisidores de Coimbra que lança luz sobre imensos aspectos. Começa por constatar a origem cristã-nova do sogro, juntando de imediato que apesar disso nunca fora acusado, ou preso pelo Santo Oficio "antes o dito seu sogro se presa tanto, que nao quis casar os seus filhos com 
cristãos-novos, e por isso casou a sua filha Clara da Silva, com ele Antonio Fernandes". O sogro, prossegue, até já fora várias vezes mordomo da confraria de Nossa Senhora do Rosário, tesoureiro da Bula da Cruzada, servira todos os cargos da governança de Melo "por via de eleição", tinha sido irmão da Misericórdia. Assim, nenhum deles trata nem conversa senão com cristãos-velhos, pelo que todos os cristãos-novos da terra lhes têm grande inveja, ódio e querem muito mal. Continua, tentando demonstrar como, quer o sogro, quer a mulher, sempre foram exemplares cristãos ${ }^{(79)}$. Isso mesmo foi confirmado por várias das testemunhas de defesa apresentadas pela ré. Uma delas, depois de confirmar que a Clara era membro de três confrarias da igreja de Melo, respectivamente a do Santíssimo Sacramento, Rosário e Jesus, diz que ela era muito boa cristã, ia sempre à missa, confessava-se e comungava, não apenas pela quaresma, quer em Melo, quer em S. Julião de Gouveia, onde iam frequentemente em romaria e era tão "afeiçoada às coisas de Deus", que até os seus criados se enfadavam de ela os obrigar a fazer tantas orações. Outra testemunha depôs ter visto inúmeras vezes a ré tirar de uma arca uma imagem do menino Jesus e "dizer lhe muitos amores", como "meu menino, meu fermoso, eu vos quero e nao quero outrem", e que quando a prenderam, levou consigo a imagem do Menino Jesus e de Nossa Senhora ${ }^{(80)}$. Por fim, o marido da Clara, demonstrando uma fina percepção quer da sociabilidade local, quer do modo como actuava a Inquisição, relatou um largo conjunto de histórias que visavam mostrar como todas as denúncias que foram feitas contra a mulher eram falsas e tinham o seu fundamento nas cizânias despoletadas por inimigos do casal. Foi ao ponto, para provar a sua razão, de mandar lavrar um auto num tabelião público, no qual testemunhas dignas de fé afiançaram, entre outros aspectos, os seguintes: que tendo ele comprado umas casas e um quintal de Diogo Fernandes, o Marquesoto de alcunha, e da mulher (dois dos processados na primeira entrada), bens que o juiz do fisco da Inquisição mandou vender em pregão, logo eles e toda a família se tornaram seus inimigos capitais, tendo desde então muitas dúvidas; que a prima que acusou a mulher à Inquisição o fizera por causa de "umas palavras afrontosas" que ele e o sogro tiveram com um irmão e um tio

(79) Cf. IAN/TT, Inquisição de Coimbra, processo $\mathrm{n}^{\circ} 2589$, fl. 13-14v.

${ }^{(80)}$ Cf. IAN/TT, Inquisição de Coimbra, processo $n^{\circ} 2589$, fl. 23 da segunda série de numeração. 
dela, ficando desde então tão inimigos que sempre que se cruzavam na rua com a mulher dele cuspiam no chão e diziam que se fossem presos "ela não andaria tão larga pela vila"; que ele e o sogro tiveram umas brigas com um Henrique Domingos, cristão-novo, que se não tivessem sido separados o tinham matado, o que fez com que, durante algum tempo, os directamente envolvidos na desordem e os parentes andassem sempre armados ${ }^{(81)}$. Na carta referida acima, conta ainda que um familiar da acusadora da sua mulher, André Gomes, também ele processado pela Inquisição, sempre que prendiam alguém pelo Santo Ofício, logo lhe ia dizer que culpassem o seu sogro e filhos, razão pela qual o sogro e ele o espancaram. Eram muitas as evidências, comprovadas por testemunhos, que mostravam a má-vontade contra a mulher. Seguramente que isso, a juntar ao facto de a Clara ter sido apenas acusada por uma única pessoa, e este empenho na sua defesa, permitiram que ela fosse apenas condenada a "abjurar de leve suspeita na fé".

Os momentos de sociabilidade entre cristãos-novos e velhos não eram muitos, a julgar pela paisagem que a janela que a documentação que aqui se compulsa deixa entrever. Para além das transacções comerciais, de empréstimos, em que por norma os cristãos-velhos eram credores e que com regularidade constituíam fonte de atrito, e da frequência de espaços comuns onde todos sabiam quem era quem, em muito pouco mais se ligariam. Viver na mesma pátria não significava de igual modo ser da mesma pátria. Melo no século XVII constitui disso um claro exemplo.

Um século após a expulsão e conversão forçada dos judeus muitas crenças e práticas judaicas se mantinham ainda no seio da comunidade cristã-nova de $\mathrm{Melo}^{(82)}$. Vestígios desgarrados de um criptojudaísmo difundido e praticado no segredo dos lares, em restritos círculos familiares, são evidentes ${ }^{(83)}$. Se bem que, globalmente, fique a impressão

(81) Cf. IAN/TT, Inquisição de Coimbra, processo n ${ }^{\circ}$ 2589, fl. 26.

(82) Uma síntese das principais crenças e preceitos judaicos pode obter-se em Elvira Mea, A Inquisição de Coimbra no século XVI..., ob. cit., pp. 459-461 e Maria José Ferro Tavares, "Judaísmo", in Carlos Moreira Azevedo (Dir.), Dicionário de História Religiosa de Portugal, Lisboa, Círculo de Leitores, 2001, vol. III, pp. 31-37.

(83) Análise semelhante a esta em relação às comunidades de cristãos-novos no nordeste brasileiro é a proposta em Bruno Feitler, Inquisition, juifs et nouveauxchrétiens au Brésil. Le Nordeste XVIIe et XVIIIe siècles, Leuven, Leuven University Press, 2003, cap. V. 
de que os fundamentos da crença já eram muito ténues, quando não totalmente desconhecidos entre os mais novos, e que a adesão ao judaísmo se preservava sobretudo através de um conjunto desarticulado de cerimónias, cuja significação profunda e primordial a maioria já desconhecia. Não tinham possibilidade de frequentar a sinagoga, $o$ acesso ao texto bíblico era raro, não possuíam mestres que perpetuassem e ensinassem de forma rigorosa os traços da sua religião, eram obrigados a esconder o que era probido pela vigilância inquisitorial e ainda tinham que mostrar, pelo menos exteriormente, a adesão a um cristianismo que, por certo, a muitos confundiria ${ }^{(84)}$. Tudo isto contribuía para a corrupção e esfacelamento da crença. Admita-se ainda que alguns dos que foram processados por judaizarem já tinham até adoptado a religião cristã em que eram obrigados a viver, mantendo apenas costumes alimentares, hábitos domésticos e de disciplina de trabalho que denunciavam a sua origem judaica. Mas outros, se executavam os gestos dos cristãos era, como diziam, por "cumprimento do mundo", ou seja, por imposição(85).

As cerimónias mais vulgarizadas que se encontram ainda relatadas em Melo, eram praticamente as mesmas que se perpetuaram noutros contextos geográficos, como, por exemplo, as elencadas por Maria José Ferro Tavares relativas aos cristãos-novos transmontanos no século $X V I^{(86)}$. Guardavam o sábado (não trabalhando, vestindo roupas lavadas e mudando o azeite e as torcidas das candeias na sexta-feira anterior), faziam alguns jejuns judaicos (o do kipur, que acontecia dez dias após a lua de Setembro, e os das segundas e quintas-feiras são os mais referidos)

(84) Alguns destes elementos foram já anteriormente muito bem captados por J. Lúcio de Azevedo, História dos cristãos-novos portugueses, ob. cit., p. 147: "Quanto mais a perseguição apertava, tanto mais as vítimas se aferravam à sua crença. Esta revestira modalidades de tal forma triviais, que se pode dizer lhe tiravam todo o carácter de religião. Sem templos nem lugares de reunião, sem ministros, esquecidos e privados da Bíblia, forçados às práticas de um culto estranho que maquinalmente executavam, seu modo de guardar a fé consistia em manterem aqueles usos domésticos que eram os principais e quase únicos cargos contra eles nos processos. As excepções reveladas na existência dos actos cultuais em comum foram raras em Portugal".

(85) Expressão utilizada, por exemplo, em IAN/TT, Inquisição de Coimbra, processo $\mathrm{n}^{\circ} 886$, fl. 9-9v.

(86) Ver Maria José Ferro Tavares, "Para o estudo dos judeus de Trás-os-Montes, no século XVI", Cultura, História e Filosofia, vol. IV, 1985, pp. 382-384. 
e preservavam certos tabús alimentares e de confecção dos alimentos (não comiam porco, lebre, coelho, peixes sem escama e não aproveitavam o sangue dos animais).

Vários depoimentos o atestam. Uns de forma simples e algo estereotipada como, por exemplo, fez um Manuel Fernandes Cáceres. Contou ele que quando tinha 13 anos lhe foi ensinado que havia um só Deus criador do Céu e da Terra, que cresse na lei que esse Deus dera a Moisés e que "por guarda da dita lei nao comesse carne de porco, perdiz, lebre, coelho, nem peixe sem escama e guardasse os sabados vestindo camisa lavada e tendo roupa lavada na cama e que no mes de Setembro jejuasse um dia sem comer até à noite ${ }^{\prime \prime(87)}$. Outros, revelando detalhes que deixam subentender maior rigor na sua execução. Veja-se por exemplo a descrição do jejum do kipur dada por Clara Pinheiro, a tal que desde o início do seu processo sustentou ser judia ${ }^{(88)}$. Nesse dia, refere, vestiam a melhor roupa, lavavam e esfregavam muito bem a casa, punham alcatifas no chão, uma taça no meio da sala com azeite novo, torcidas novas acesas. E estando todos descalços, em pé, sem se sentarem toda a noite, rezavam orações até ao nascer do sol, sem comer, beber, ou acender fogo ${ }^{(89)}$. A mesma ré apresenta relatos da preparação da carne dizendo que quando ela vinha do açougue, lhe tirava o sangue, a lançava em água e sal lavando-a em três águas diferentes, com uma faca pequena tirava os pedaços que tinham sido corrompidos pelo toque da faca do açougue, extraía-lha a gordura e depois punha-a numa panela com azeite e cebola ${ }^{(90)}$.

Raríssimas, mas ainda presentes, eram as alusões a bençãos, orações, rituais praticados cọm os defuntos no interior do lar e à Páscoa do pão ázimo (a pesahe). Clara Pinheiro continua a ser o melhor repositório. É a única que refere ter participado em orações colectivas nas quais se liam os salmos de David "por um livro branco", confessando ainda algumas das orações com que dizia adorar "Deus dos Céus", como por exemplo a seguinte: "Bendito e louvado seja o nome do meu senhor Adonai que

(87) Cf. IAN/TT, Inquisição de Coimbra, processo $\mathrm{n}^{\circ}$ 1458, fl. não numerado.

(88) Significativamente, o seu processo é aquele onde se podem colher mais referências a cerimónias e até a orações judaicas.

(89) Cf. IAN/TT, Inquisição de Coimbra, processo $n^{\circ} 5735$, fl. 27v.

(90) Cf. IAN/TT, Inquisição de Coimbra, processo nº 5735, fl. 27. 
nos deixou e nos encomendou nas suas santas encomendanças, santas, benditas e santas que nos lavassemos com agoas limpas e claras para que assim fossem as nossas almas limpas e claras diante de sua divina magestade" ${ }^{\prime(91)}$. No processo de um Fernão Gomes encontram-se descrições de cerimónias feitas com os defuntos. Quando alguém morria lavavam-lhe o corpo com água fria e clara "tendo aparelhado para isso dous cantaros de agoa, e avendo lavado ao defunto aviam de derramar toda a agoa que ouvesse crecido dos cantaros na rua; e que isto se fazia em honra de Moises e para que não quedasse memoria nem rasto daquela morte em casa; e que logo aviam de tomar hum pedaço de linho cru do tamanho de hum real e lho aviam de por ao dito defunto debaixo da lingoa, para que na outra vida fosse conhecido [...] que era do povo de Israel; e que depois de enterrado o defunto aviam de por em o aposento onde foi morto huma mesa com huns manteos limpos e hum jarro de agoa". No quarto deviam ainda colocar-se uma candeia com azeite e pavios que se renovavam todas as noites. Estas cerimónias deviam durar três dias e três noites, permanecendo o quarto sempre fechado ${ }^{(92)}$. Relato semelhante, produz Clara Pinheiro, mas ainda com alusão a ofertas de comida que se deviam fazer ao defunto e menção a que durante certos dias não se devia comer nada que fosse cozinhado na casa onde estava o morto ${ }^{(93)}$. Quanto às bençãos, que consistiam em percorrer o rosto de quem se benzia com a palma da mão aberta até se chegar ao peito, nomeando os nomes de Abraão, Isaac e Jacob, são relatadas, por exemplo, por uma Maria Lopes, que dizia que o seu pai a benzia "a modo judaico"(94).

Outras marcas das suas origens e crenças tinham-se extinguido por completo, sobretudo aquelas que, por evidentes e mais visíveis, facilmente denunciariam a sua crença: os nomes judaicos, a utilização do hebraico, a circuncisão, o enterro dos defuntos em "terra virgem".

Note-se ainda que muitos acusados referiam cerimónias já muito adulteradas, indiciadores ou de uma corrupção provocada pelo segredo com que tudo tinha que ser feito ou/e ainda de falsas confissões. Isso se passava com a Páscoa do pão ázimo, referida por Brites Gomes como

(91) Cf. IAN/TT, Inquisição de Coimbra, processo n ${ }^{\circ} 5735$, fl. $24 \mathrm{v}$.

(92) Cf. IAN/TT, Inquisição de Coimbra, processo no ${ }^{\circ}$ 5129, fl. 5-6.

(93) Cf. IAN/TT, Inquisição de Coimbra, processo n ${ }^{\circ} 5735$, fl. 25v.

(94) Cf. IAN/TT, Inquisição de Coimbra, processo $\mathrm{n}^{\circ}$ 886, fl. não numerado (sessão de confissão de 8 de Janeiro de 1602). 
uma cerimónia que faziam anualmente, estando todos os cristãos-novos juntos em que se ofereciam "bolos asmos"(95). Um André Gomes, por exemplo, dizia que uma tia, Genebra Gomes, lhe havia ensinado que fizesse uns jejuns em honra "da rainha Estrela", "que hera huma rainha grande" (alusão aos jejuns da rainha Esther que aconteciam durante os meses de Fevereiro/Março) e que "adorasse a toura que saira do ouro e das joias dos filhos de Israel"(96).

A aprendizagem destas cerimónias fazia-se em segredo, no interior do lar e as mulheres parece terem tido um papel fulcral na sua transmissão. Se não foi o resultado de uma estratégia globalmente difundida destinada a preservar os elementos masculinos, o que é certo é que a maioria dos relatos onde este ponto é focado apresentam as mães, avós e sobretudo tias solteiras como as principais perpetuadoras e divulgadoras de crença ${ }^{(97)}$. Por outro lado, e como tudo tendia a ser mantido em segredo, a constatação de que certos indivíduos preservavam cultos judaicos ocorria, por vezes, em situações caricatas. Uns rapazes contam que souberam uns dos outros porque indo pescar ao Mondego, perto de Folgosinho, pescaram enguias e não as quiseram comer, por ser peixe sem escama e defeso na sua lei( ${ }^{(98)}$.

\section{Os efeitos do choque}

As entradas praticadas pela Inquisição em pequenas localidades como Melo deixavam marcas profundas e duradouras. Desde que se faziam as primeiras prisões, por vezes já anteriormente pressentidas pela realização de comissões de audição de testemunhas ordenadas pelo Santo Ofício ${ }^{(99)}$,

(95) Cf. IAN/TT, Inquisição de Coimbra, processo $\mathrm{n}^{\circ}$ 886, fl. não numerado (testemunhas de acusação, depoimento de Brites Gomes).

(96) Cf. IAN/TT, Inquisição de Coimbra, processo n $\mathrm{n}^{\circ} 7308$, fl. 10v-11.

(97) Ver, por exemplo, para o caso de uma tia como raiz de todos os conhecimentos IAN/TT, Inquisição de Coimbra, processo $n^{\circ} 2869$, fl. 41-43.

(98) Cf. IAN/TT, Inquisição de Coimbra, processo $n^{\circ} 1458$, fl. não numerado (depoimentos das testemunhas de acusação).

(99) Pese embora o enorme cuidado e segredo que se pretendia manter. A primeira questão que era colocada àqueles que eram chamados como testemunhas, era se eles sabiam ou suspeitavam porque estavam a ser inquiridos e o segredo de tudo era-lhes exigido. 
e até à saída em auto-da-fé dos derradeiros processados, instalava-se um clima de medo, intranquilidade, por vezes de autêntico "terrorismo" psicológico. Medo e intranquilidade que decorriam das ligações familiares com os que eram encarcerados. Medo e intranquilidade que eram constantemente alimentados por múltiplas ameaças, feitas quer por cristãos-velhos, quer por cristãos-novos. Na prática, no interior da comunidade cristã-nova, todos se receavam mutuamente, particularmente aqueles com quem se alimentara algum desentendimento.

Em Melo, nos primeiros anos do século XVII, o prior não tinha qualquer pudor em usar o púlpito para ofender os "judeus", para os ameaçar de que os "levaria a Coimbra" e para asseverar que faria da vila uma "quinta" para si e seus primos ${ }^{(100)}$. E os do seu "bando" acompanha-lo-iam. Mas também já se viu, ao reportar-se o caso de Clara da Silva, como as ameaças dos cristãos-novos uns em relação aos outros contribuíam para criar um ambiente de intimidação. Uma vez presos, alguns dos réus não se esquecem disso e usam-no para tentar contestar algumas das acusações que sobre si julgavam impender. Por exemplo, uma Genebra Gomes, apresentou contraditas contra uma Guiomar Gomes, sua sobrinha, contando que, doze anos antes da sua prisão, a sobrinha lhe matara uma filha queixando-se de ela ter uma relação ilícita com o seu marido. Por esse motivo, Guiomar desonrava-lhe publicamente as filhas e um dia foi com as filhas dela à sua porta e "lhes deu muitas pedradas que as matavão se nao acudia gente", acrescentando que no decorrer da briga apareceu o marido da Guiomar que deu com um ferro na cabeça de uma filha da Genebra, de que ela veio a falecer. Desde então, tinham ficado inimigas e ela sempre receou que um dia a Guiomar lhe pudesse levantar falsos testemunhos ${ }^{(101)}$. Uma vez presa a Guiomar, a Genebra não mais deve ter sossegado e, de facto, acabou por ser presa com base numa acusação desta sobrinha ${ }^{(102)}$.

${ }^{(100)} \mathrm{Cf}$. IAN/TT, Inquisição de Coimbra, processo n 2589, fl. 29.

${ }^{(101)} \mathrm{Cf}$. IAN/TT, Inquisição de Coimbra, processo $\mathrm{n}^{\circ}$ 7308, fl. 42.

(102) O seu processo é ainda um bom exemplo de que o "segredo inquisitorial" tinha falhas. Segundo um depoimento do familiar que a prendeu, pernoitando eles uma noite numa estalagem em Pinhanços, quando vinham a caminho de Coimbra, a estalajadeira teria dito à Genebra que não "desse" em ninguém e que pusesse contraditas em Guiomar Gomes, o que é muito sugestivo, pois a Genebra tinha sido mandada prender com base no testemunho singular da Guiomar, ver IAN/TT, Inquisição de Coimbra, processo n 7308, fl. 9v. 
Estes exemplos alertam para ofacto de que os conflitos numa comunidade não acontecem apenas entre indivíduos ou grupos de etnias diferentes. A proximidade convivial e familiar no interior de cada universo era, por vezes, factor potenciador de desentendimentos e rancores mais profundos do que os que afloravam entre indivíduos que, por terem origens marcadamente distintas, mais raramente contactavam. Poder-se-ia dizer que a segregação e intolerância, por paradoxal que isso possa parecer, dificultavam a emergência de conflitos $e$, nesse sentido, podiam ser factores que acabavam por contribuir para a sustentabilidade da existência de distintos grupos numa mesma localidade.

Por vezes, pressente-se um ambiente de autêntico terrorismo que colocava em alvoroço as famílias descendentes dos judeus. Num dos processos compulsados aparece mesmo a notícia de que o prior de Melo e os seus primos, durante a noite, metiam cartas pelos buracos das portas dos cristãos-novos instando-os a que fugissem, senão seriam presos ${ }^{(103)}$.

E fugir e "pôr a fazenda em seguro" eram os meios mais comuns para evitar os castigos, a infâmia e os prejuízos que uma intervenção do Santo Ofício causava. Há muitos relatos de que mal começavam as prisões, sobretudo os homens, e quando podiam levando filhos e fazenda, fugiam. Por vezes são familias inteiras. Uma Ana Gomes da Silva, que se apresentou na Inquisição de Coimbra em sete de Janeiro de 1671, já era a única da familia que permanecia em Portugal, pois o pai morrera, a mãe e todos os irmãos tinham fugido para Lugo (Espanha) e alguns tios tinham-se refugiado em Málaga ${ }^{(104)}$. O vizinho reino de Castela era o destino mais comum. Alguns acabavam por ser lá capturados e julgados por tribunais da Inquisição espanhola. Um Rodrigo Mendes, sentenciado em 1670, denunciou um irmão que tinha fugido há dois anos para Tânger, outro que foi para Madrid e de lá remetido para a Inquisição de Toledo, onde saiu reconciliado e ainda tios e primos, alguns deles também fugitivos em Madrid ${ }^{(105)}$.

${ }^{(103)}$ Cf. IAN/TT, Inquisição de Coimbra, processo n ${ }^{\circ} 2589$, fl. 29.

${ }^{(104)} \mathrm{Cf}$. IAN/TT, Inquisição de Coimbra, processo $n^{\circ} 6320$, fl. não numerado (sessão de genealogia).

${ }^{(105)} \mathrm{Cf}$. IAN/TT, Inquisição de Coimbra, processo $\mathrm{n}^{\circ}$ 6836, fl. não numerado (sessões de confissão do réu). 
É que fugir para perto, tentando não deixar rasto e esconder origens nos novos pontos de residência, podia não ser eficaz. Mostra-o bem Henrique Mendes, mercador "rico e abonado", com parentes advogados e médicos, que saiu de Melo e foi morar para a freguesia do Botão, perto de Coimbra, durante a primeira entrada, em 1601. Acabou por ser preso em 1604, tendo sido salvo pelo perdão geral de 1605. Mas os inquisidores não lhe perdem a pista e, em 1623, num segundo processo, foi relaxado ao braço secular ${ }^{(106)}$. Destino idêntico ao de um filho, Manuel Mendes, cerca de quatro anos após a condenação do pai ${ }^{(107)}$.

E alguns réus, ingenuamente, fazendo confiança nos almocreves que os acompanhavam até aos cárceres em Coimbra davam-lhes recados, como o que Maria Lopes segredara a Belchior Francisco. Pedira-lhe esta rapariga que quando regressasse a Melo fosse ter com um Antão Mendes Chorão, mercador de panos, e lhe dissesse que "pusesse a sua fazenda em seguro", que muito lhe custara a ganhar ${ }^{(108)}$.

As fugas aumentaram em Melo com o decorrer do tempo, prova de que as comunidades cristãs-novas ficavam de sobreaviso mal a Inquisição começava a actuar. De facto, se a segunda entrada em Melo não foi tão ampla como a primeira, isso em boa medida se deveu à grande quantidade de cristãos-novos que tinham abandonado a terra, como se comprova pelos relatos daqueles que foram presos. Das cerca de duas dezenas de réus da segunda entrada, a esmagadora maioria referem parentes que haviam fugido.

Acresce que os que eram presos e respectivas famílias passavam por situações muito traumatizantes o que, por certo, deixava duradouras marcas difíceis de cicatrizar, mesmo em sociedades particularmente violentas como eram as do Antigo Regime. Recordo apenas uma ré que, quando foi presa, deixou sozinhos em casa dois filhos pequenos, um de cinco e outro de dois anos, e que deu à luz um terceiro filho, nos cárceres, pouco tempo após a sua chegada ${ }^{(109)}$.

${ }^{(106)}$ Cf. IAN/TT, Inquisição de Coimbra, processos n 5072 e 6845.

${ }^{(107)}$ Cf. IAN/TT, Inquisição de Coimbra, processo n 6146.

${ }^{(108)} \mathrm{Cf}$. IAN/TT, Inquisição de Coimbra, processo $\mathrm{n}^{\circ} 886$, fl. não numerado (depoimentos das testemunhas da acusação).

${ }^{(109)}$ Cf. IAN/TT, Inquisição de Coimbra, processo $n^{\circ} 892$, particularmente o depoimento de um familiar do Santo Ofício que a prendeu, ver fl. não numerado no início do processo. 
Para além disso, após a prisão, as possibilidades de reintegração na vida local eram muito dificultadas, pela falta de meios causada pelos confiscos, pela destruição das famílias, pela aversão dos conterrâneos. Ana Pinheiro, moça solteira, de 17 anos, apanhada na segunda entrada, conjuntamente com os pais, dois irmãos, duas irmãs, duas tias maternas e uma cunhada, foi condenada a abjurar em forma com pena de cárcere e hábito penitencial perpétuos, no auto-da-fé de 13 de Fevereiro de 1667. Em sete de Março desse ano, depois de ter sido instruída espiritualmente, foi mandada ir em liberdade. Cerca de dois anos depois, em três de Junho de 1669, é-lhe autorizado que deixe de usar o hábito de penitenciada. Por essa altura, o prior de Melo envia uma nota para o Santo Ofício de Coimbra onde atesta: "consta que esta ree se foi para a villa de Linhares, por the morrer sua mai Francisca Pinheira e lhe nao ficar em Mello pessoa com quem vivesse e a levarão doente para a dita villa de Linhares para casa de huns primos"(110). O pai de Ana era mercador e rendeiro, quando o levaram em quatro de Setembro de 1664. Faleceu nos cárceres e foi relaxado em "ossos e estátua"(111). Cinco anos depois, já não havia em Melo ninguém da sua famila que pudesse ou quisesse amparar a filha.

Um Simão Gomes, tendeiro e pisoeiro, preso durante a primeira entrada, na qual quase todos os irmãos, cunhados e sobrinhos foram envolvidos, depois de solto fugiu para Castela. A mulher, foi queimada nos areais do Mondego, no auto-da-fé celebrado em 1608. Os filhos permaneciam em Melo, por finais de 1608 e prometiam vingar-se dos acusadores de seus pais ${ }^{(112)}$.

Os que ficavam em Melo passavam muitas dificuldades e dificilmente reorganizavam suas vidás. Em 1669, um familiar do Santo Ofício de Melo, conta que vindo da igreja, encontrara uma Leonor Nunes, ré que havia sido condenada a confisco de todos os bens e uso de hábito penitencial, com uns anéis de ouro nos dedos e umas arrecadas nas orelhas, pelo que lhos retirou e deu ao comissário local da Inquisição ${ }^{(113)}$. Mas a história

\footnotetext{
${ }^{(110)}$ Cf. IAN/TT, Inquisição de Coimbra, processo $\mathrm{n}^{\circ}$ 5566, fl. não numerado (últimos documentos do processo).

(111) Cf. IAN/TT, Inquisição de Coimbra, processo $n^{\circ} 4688$.

${ }^{(112)}$ Cf. IAN/TT, Inquisição de Coimbra, processo $n^{\circ} 2589$, fl. não numerado (depoimentos das testemunhas de contraditas).

${ }^{(113)} \mathrm{Cf}$. IAN/TT, Inquisição de Coimbra, processo $\mathrm{n}^{\circ} 7045$, fl. não numerado (últimos documentos do processo).
} 
mais ilustrativa é a narrada por Catarina de Cáceres, a única ré que estabelece uma ligação entre a primeira e a segunda entrada, pois foi presa na segunda, com 66 anos de idade, e o pai dela na primeira. Na sessão de genealogia reproduziu o sucedido a toda a sua geração que tinha sido perseguida na primeira entrada de Melo. Os tios todos se tinham ausentado do reino, uns após terem sido condenados, outros fugindo antes, três irmãos e três irmãs dela todos morreram solteiros, sendo ainda viva, quando ela foi presa, uma irmã, também solteira. A condenação do pai, que era um rico mercador originário de Aveiro e que tinha ido casar a Melo com a mãe da ré, impossibilitou o percurso matrimonial de praticamente toda a sua descendência ${ }^{(114)}$.

Para além destes aspectos da vida individual de cada um, que a memória histórica não deve esquecer, os efeitos sobre a comunidade globalmente considerada eram severos: despovoamento, empobrecimento, desestruturação de certos sectores da produção económica. Estas eram as marcas deixadas por uma entrada inquisitorial. A lógica do que sucedia é facilmente perceptível. Como a fuga dos cristãos-novos era a solução habitualmente encontrada, isso tinha reflexos nítidos nas estruturas demográficas locais ${ }^{(115)}$. Os fugitivos levavam consigo o seu saber, força e dinâmica de trabalho e, naturalmente, quando podiam, alguns bens móveis, o que transformava a terra num local globalmente mais pobre. Por outro lado, o peso que tinham em certas áreas, como a produção de

${ }^{(114)}$ Cf. IAN/TT, Inquisição de Coimbra, processo $n^{\circ} 326$, fl. não numerado (sessão de genealogia).

(115) Outros historiadores já o constataram para a globalidade do território do reino, ver J. Lúcio de Azevedo, História dos cristãos-novos portugueses, ob. cit., p. 136: "Deste sistema de defesa, a que as normas processuais conduziam, provinha despovoarem-se pequenas localidades, onde eram em grande número os cristãos-novos. Preso o primeiro, os restantes sabendo o que os esperava, desapareciam". (116) Cf. António Borges Coelho, Inquisição de Évora. Dos primórdios a 1668, Lisboa, Editorial Caminho, 1987, vol. II, pp. 32-34. Mais discutível, se não mesmo insustentável é, no meu parecer, a tese que Borges Coelho apresenta ao apreciar este facto, quando entende que a Inquisição foi "a principal responsável pela travagem do desenvolvimento económico e social em Portugal, pelo mergulhar progressivo no subdesenvolvimento e na colonização dos nossos comércios e riquezas pelos capitais estrangeiros, empurrando-nos progressivamente, de um lugar destacado, para a cauda do desenvolvimento europeu", vol. II, p. 35. 
panos e sua mercancia, provocava que com a sua fuga todas as actividades económicas a elas ligadas ficassem totalmente desarticuladas, criando crises que não devem ter sido fáceis de superar, confirmando interpretações já propostas por Borges Coelho para outros espaços, ao afirmar que "o fogo inquisitorial" travou o desenvolvimento económico, enfraqueceu os concelhos, desconjuntou o mercado interno, desorganizou a produção local, gerou subdesenvolvimento ${ }^{(116)}$.

Parte da riqueza patrimonial deixada, quer pelos presos, a quem na maioria dos casos eram confiscados os bens, quer pelos que fugiam, mudariam de mãos, vendidos pelo juiz do fisco. Mas isso, apesar dos baixos valores com que por norma seriam arrematados, implicava sempre sangria de capitais locais em direcção aos cofres do fisco real. Além disso, estas mudanças de propriedade, como já se relatou, muitas vezes constituiriam fonte de atritos a nivel local, quer entre familiares dos velhos proprietários dos bens e os seus novos detentores, quer, em certos casos, entre os candidatos aos novos bens que não os conseguiram comprar e os que de facto os adquiriram. Ou seja, todas estas trocas que implicavam simultaneamente processos de empobrecimento e de enriquecimento, acabavam por transformar a própria configuração dos equilíbrios sociais e económicos locais, o que faria com que a comunidade necessitasse de tempo para se adaptar às novas realidades criadas.

Melo ficou mais pobre e ficou outra após as entradas da Inquisição a que foi sujeita, no século XVII. A história das transformações seguintes e da alteração da sua idẹntidade já não me compete revelá-las no âmbito deste estudo. Mas cumpre-me recordar aquilo que, trezentos e cinquenta anos depois, em Melo e terras vizinhas já ninguém lembrava, a propósito da violência com que em Seiscentos aquela vila serrana fora sacudida pelo Tribunal da Fé. 


\section{Anexo 1}

Lista dos processados pela Inquisição naturais e/ou residentes em Melo

\begin{tabular}{|c|c|c|c|}
\hline Ano do Auto & Nome do réu & Tribunal & $N^{o}$ do Processo \\
\hline 1558 & GUIOMAR DO CAMPO & Lisboa & 5248 \\
\hline 1562 & GUIOMAR DO CAMPO & Lisboa & 5248 \\
\hline 1570 & ANTONIA DO CAMPO & Coimbra & 9123 \\
\hline 1571 & HENRIQUE FERNANDES & Coimbra & 1391 \\
\hline 1571 & VIOLANTE VAZ & Coimbra & 10038 \\
\hline 1587 & GRAÇA DIAS & Lisboa & 5797 \\
\hline 1590 & FRANCISCO GONÇALVES & Coimbra & 7119 \\
\hline \multicolumn{4}{|l|}{$1^{a}$ Entrada } \\
\hline 1602 & ANA DIAS & Coimbra & 892 \\
\hline 1602 & ANA DO CAMPO & Coimbra & 1731 \\
\hline 1602 & ANA FERNANDES & Coimbra & 902 \\
\hline 1602 & ANDRE GOMES & Coimbra & 906 \\
\hline 1602 & BRITES TELES & Coimbra & 2078 \\
\hline 1602 & CATARINA MANUEL & Coimbra & 2407 \\
\hline 1602 & CLARA GOMES & Coimbra & 912 \\
\hline 1602 & GASPAR LOPES & Coimbra & 4253 \\
\hline 1602 & GENEBRA GOMES & Coimbra & 7308 \\
\hline 1602 & GUIOMAR GOMES & Coimbra & 7618 \\
\hline 1602 & ISABEL DO CAMPO & Coimbra & 7306 \\
\hline 1602 & LEONOR FERNANDES & Coimbra & 1739 \\
\hline 1602 & LEONOR FERNANDES & Coimbra & 8807 \\
\hline 1602 & MARIA DO CAMPO & Coimbra & 9107 \\
\hline 1602 & MARIA LOPES & Coimbra & 886 \\
\hline 1602 & PEDRO FERNANDES & Coimbra & 2396 \\
\hline 1602 & RUI TELES & Coimbra & 10104 \\
\hline 1605 & ANA FERNANDES & Coimbra & 3118 \\
\hline 1605 & ANA FERNANDES & Coimbra & 3119 \\
\hline 1605 & ANA GOMES & Coimbra & 3117 \\
\hline 1605 & ANTONIA DO CAMPO & Coimbra & 6545 \\
\hline 1605 & ANTONIO MENDES & Coimbra & 3110 \\
\hline 1605 & BEATRIZ GOMES & Lisboa & 5693 \\
\hline 1605 & BRANCA DINIS & Coimbra & 9657 \\
\hline 1605 & BRANCA LOPES & Coimbra & 3111 \\
\hline
\end{tabular}




\begin{tabular}{|c|c|c|c|}
\hline Ano do Auto & Nome do réu & Tribunal & $N^{o}$ do Processo \\
\hline 1605 & BRANCA RODRIGUES & Coimbra & 8963 \\
\hline 1605 & BRITES GOMES & Coimbra & 10338 \\
\hline 1605 & CLARA DIAS & Coimbra & 895 \\
\hline 1605 & DIOGO FERNANDES CÁCERES & Coimbra & 188 \\
\hline 1605 & DIOGO FERNANDES MARQUESOTO & Coimbra & 6478 \\
\hline 1605 & FERNÃO GOMES & Coimbra & 5129 \\
\hline 1605 & HENRIQUE DIAS & Coimbra & 9826 \\
\hline 1605 & HENRIQUE MENDES & Coimbra & 5072 \\
\hline 1605 & ISABEL FERNANDES & Coimbra & 10531 \\
\hline 1605 & ISABEL GOMES & Coimbra & 10294 \\
\hline 1605 & ISABEL NUNES & Coimbra & 1920 \\
\hline 1605 & JOÃO ESTEVES & Coimbra & 3108 \\
\hline 1605 & JORGE FERNANDES & Coimbra & 7291 \\
\hline 1605 & JORGE LOPES & Coimbra & 878 \\
\hline 1605 & LEONOR GOMES & Coimbra & 10406 \\
\hline 1605 & LUISA GOMES & Coimbra & 4801 \\
\hline 1605 & MANUEL FERNANDES CÁCERES & Lisboa & 1458 \\
\hline 1605 & MARIA GOMES & Coimbra & 9513 \\
\hline 1608 & ANTONIA DO CAMPO & Coimbra & 201 \\
\hline 1608 & BRITES GOMES & Coimbra & 8037 \\
\hline 1608 & CATARINA LOPES & Coimbra & 2584 \\
\hline 1608 & CLARA RODRIGUES & Coimbra & 2601 \\
\hline 1608 & DIOGO DO CAMPO & Coimbra & 3946 \\
\hline 1608 & SIMÃO GOMES & Coimbra & 2915 \\
\hline 1610 & ANTONIA RODRIGUES & Coimbra & 2602 \\
\hline 1610 & CLARA DA SILVA & Coimbra & 2589 \\
\hline 1610 & CLARA DIAS & Coimbra & 2588 \\
\hline 1610 & FILIPA RODRIGUES & Coimbra & 2586 \\
\hline 1612 & MANUEL LOPES & Coimbra & 793 \\
\hline 1623 & DUARTE FERNANDES TELES & Coimbra & 4727 \\
\hline 1623 & HENRIQUE MENDES & Coimbra & 6845 \\
\hline 1627 & MANUEL MENDES & Coimbra & 6146 \\
\hline \multicolumn{4}{|l|}{$2^{\mathrm{a}}$ Entrada } \\
\hline 1655 & GASPAR RODRIGUES FROIS & Coimbra & 4688 \\
\hline 1667 & GASPAR RODRIGUES FROIS & Coimbra & 4688 \\
\hline 1667 & ANA PINHEIRO & Coimbra & 5566 \\
\hline
\end{tabular}




\begin{tabular}{cccc} 
Ano do Auto & Nome do réu & Tribunal & $N^{\circ}$ do Processo \\
\hline 1667 & ANTONIO PINHEIRO & Coimbra & 7441 \\
1667 & FRANCISCA PINHEIRA & Coimbra & 4297 \\
1669 & CLARA PINHEIRO & Coimbra & 5735 \\
1669 & LEONOR NUNES & Coimbra & 7045 \\
1669 & MANUEL DIAS & Lisboa & 1502 \\
1670 & RODRIGO MENDES & Coimbra & 6826 \\
1671 & ANA GOMES DA SILVA & Coimbra & 6320 \\
1671 & ANTONIO RODRIGUES & Coimbra & 9695 \\
1671 & BRANCA RODRIGUES & Coimbra & 6387 \\
1671 & JORGE RODRIGUES ANDRADE & Coimbra & 9894 \\
1671 & MANUEL RODRIGUES FROIS & Coimbra & 505 \\
1672 & MARIA PINHEIRA & Coimbra & 4344 \\
1673 & FRANCISCO MENDES PINHEIRO & Coimbra & 9206 \\
1673 & FRANCISCA NUNES & Coimbra & 9194 \\
1673 & MIGUEL DA COSTA & Coimbra & 4756 \\
1673 & TOMAS RODRIGUES & Coimbra & 2801 \\
1674 & CATARINA DE CÁCERES & Coimbra & 326 \\
$3^{\mathrm{a}}$ Entrada & & & \\
1691 & CLARA DE GOUVEIA & Coimbra & 1118 \\
1691 & JERONIMO CARDOSO & Coimbra & 7900 \\
1691 & JOSÉ NUNES & Coimbra & 7901 \\
1691 & MANUEL RODRIGUES & Coimbra & 7896 \\
1691 & MARIA DE GOUVEIA & Coimbra & 7886 \\
1696 & CATARINA DA SILVA & Coimbra & 2869 \\
1752 & JACINTA INÁCIA ROSA & Lisboa & 734
\end{tabular}

